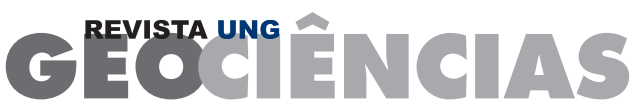

ISSN1981-741X

\section{DOI: 10.33947/1981-741X-v20n1-4785 \\ CRISE AMBIENTAL E A DESNATURAÇÃO DA POLÍTICA NACIONAL DO MEIO AMBIENTE NO BRASIL}

\author{
ENVIRONMENTAL CRISIS AND THE DENATURATION OF THE NATIONAL ENVIRONMENT \\ POLICY IN BRAZIL
}

\author{
Luciana Lima Domingues de Souza ${ }^{1}$, Fernando Zanatta² ${ }^{2}$ Diego de Melo Conti ${ }^{3}$, Cândido Ferreira da Silva Filho ${ }^{4}$
}

\begin{abstract}
Submetido em: 15/10/2021
\end{abstract}
Aprovado em: 09/11/2021

\section{RESUMO}

O Brasil vive uma severa crise ambiental, a qual atinge sua culminância com o desmonte da Política Nacional do Meio Ambiente. As recentes mudanças nas políticas ambientais realizadas desde 2019 pelo governo brasileiro têm sido amplamente repercutidas de maneira negativa nas comunidades científicas nacionais e internacionais, trazendo à tona a importância dos biomas brasileiros para o desenvolvimento sustentável do planeta. Este artigo teve como objetivo investigar e refletir sobre os encontros e desencontros da Lei no. 6.938, de 31 de agosto de 1981, discutindo a Política Nacional do Meio Ambiente na atualidade. Para isso, foi realizada uma pesquisa de caráter exploratório e de abordagem qualitativa, baseando-se em uma revisão de literatura. A análise dos dados foi realizada pelo método de abordagem sistêmico-complexo. Os resultados indicam que houve uma desnaturação da Política Nacional do Meio Ambiente, tornando assim a lei branda e até mesmo ineficaz para a preservação do patrimônio ambiental do Brasil.

PALAVRAS-CHAVE: Ambiente. Agenda ambiental brasileira. Política de desmantelamento.

\section{ABSTRACT.}

Brazil is experiencing a severe environmental crisis, which culminates with the dismantling of the National Environmental Policy. The recent changes carried out since 2019 by the Brazilian government have been widely reflected negatively in the national and international scientific communities, bringing to light the importance of Brazilian biomes for the sustainable development. This article aimed to investigate and reflect on the encounters and disagreements of Law no. 6,938, of August 31, 1981, discussing the current National Environmental Policy. For this, exploratory research with a qualitative approach was carried out, based on a literature review. Data analysis was performed using the complex-systemic approach method. The results indicate that there was a denaturation of the National Environmental Policy, thus making the law ineffective for the preservation of Brazil's environmental heritage.

KEYWORDS: Environment. Brazilian environmental agenda. Dismantling policy.

\footnotetext{
1 Pontifícia Universidade Católica de Campinas, Centro de Economia e Administração, Programa de Pós-graduação em Sustentabilidade

2 Pontifícia Universidade Católica de Campinas, Centro de Economia e Administração, Programa de Pós-graduação em Sustentabilidade

3 Pontifícia Universidade Católica de Campinas, Centro de Economia e Administração, Programa de Pós-graduação em Sustentabilidade

4 Pontifícia Universidade Católica de Campinas, Centro de Economia e Administração, Programa de Pós-graduação em Sustentabilidade
} 


\section{INTRODUÇÃO}

O Brasil está no topo da lista dos 18 países megabiodiversos do planeta (UNEP, 2019). O meio ambiente e a abundância de recursos naturais são ativos que têm propiciado o crescimento econômico ao longo das últimas décadas, o que de acordo com Veiga (2005), pode ser compreendido como o processo de desenvolvimento. Assim, o principal indicador de desenvolvimento de uma nação seria o Produto Interno Bruno (PIB) que representa a soma de todos os bens e serviços produzidos em um determinado espaço de tempo e, com isso, a premissa fundamental do desenvolvimento seria o crescimento econômico de um país.

A ideia de desenvolvimento fundamentado no crescimento econômico parece ter sido a tônica do Brasil durante o período conhecido como milagre econômico brasileiro (1969 a 1973). Dentro deste contexto, a adoção de políticas públicas estruturadas com o objetivo de promoção do desenvolvimento de determinadas regiões foi um mecanismo adotado no Brasil a partir dos anos 1950, com a criação de autarquias e órgãos públicos como o Banco do Nordeste do Brasil (BNB), a Superintendência do Plano de Valorização Econômica da Amazônia (SPVEA), a Superintendência do Desenvolvimento da Amazônia (Sudam), a Superintendência do Desenvolvimento do Nordeste (Sudene) e a própria Zona Franca de Manaus (CAVALCANTE, 2018), porém com interrupções de suas existências públicas envoltas em atos de corrupção e manipulações contra o interesse público.

Com esse viés, a Sudam e a Sudene foram extintas em 2001 envoltas em denúncias de corrupção, desvios de verbas e ineficiência de gestão. Posteriormente, em 2007, a Sudam e Sudene foram recriadas sob fortes críticas, uma vez que, por cinco décadas, não transformaram o desenvolvimento socioeconômico das cidades atingidas (HORSTH; DE ALMEIDA; MENDES, 2017). Cavalcante (2018) destaca que iniciativas como essas são atualmente consistentes com vários dispositivos da Constituição Federal, que tratam da redução das desigualdades por meio de mecanismos geoeconômicos e sociais.

Contudo, as questões ambientais continuam a ser o pano de fundo para tensionamento político e social, principalmente no que se refere ao uso e ocupação do solo e a exploração dos recursos naturais. De tal modo, Capelari et al., (2020, p. 1692) ressaltam que "o subsistema de política ambiental no Brasil é complexo e mudou muito nos últimos trinta anos". Contudo, mesmo com os tensionamentos, distensões e vulnerabilidades, o modelo brasileiro, que envolve participação das três esferas da federação, até 2012 obteve êxito na proteção dos recursos naturais (CAPELARI et al., 2020). Apesar disso, em janeiro de 2019, com a posse de um governo conservador e sem compromisso com a agenda ambiental, profundas mudanças têm sido implementadas na condução da política socioambiental brasileira, tanto na alocação de recursos, quanto no funcionamento de suas instituições (CAPELARI, et al., 2020).

A mudança de postura do governo brasileiro tem sido amplamente repercutida na imprensa nacional e internacional como, por exemplo: (i) a forma com que o governo federal lidou com as grandes queimadas na Amazônia e Cerrado; (ii) a dubiedade de posicionamento acerca do Acordo de Paris e as mudanças do clima; (iii) a desqualificação sistemática do trabalho científico de monitoramento de desmatamento realizado pelo Instituto Nacional de Pesquisas Espaciais (INPE); (iv) o entrevero envolvendo o Fundo da Amazônia e financiadores internacionais; ( $v$ ) as propostas de exploração econômica de reservas indígenas para fins agrícolas e de mineração; (vi) a extinção de comitês paritários de participação social; (vii) o esvaziamento da Comissão Nacional de Meio Ambiente (CONAMA); (viii) o discurso sobre a necessidade de regularização fundiária de ocupações ilegais; (ix) as tentativas em restringir e controlar a atuação de organizações não-governamentais (ONG); (x) o distanciamento das iniciativas multilaterais; ou, então, (xi) o tensionamento constante para a redução da extensão de áreas protegidas.

Por outro lado, percebe-se que são inúmeras as intervenções em matérias socioambientais que representavam avanços significativos do país nessa seara, sendo esse o pano de fundo do ora acerca da desnaturação da Política Nacional do Meio Ambiente - Lei Federal no. 6.938/1981, como mais um estratagema de desmonte das instituições democráticas e da agenda verde no Brasil. Sendo assim, este artigo teve como objetivo investigar e refletir sobre os encontros e desencontros da Lei no. 6.938, de 31 de agosto de 1981 (BRASIL, 1981) nas arenas de coalizão política e, finalmente, o resultado de sua efetividade diante das novas diretrizes impostas pelo retrocesso normativo socioambiental, o qual, paulatinamente, vem minando as 
políticas públicas do país na construção de seu Estado Ambiental de Direito desde a Carta Magna de 1988.

\section{FUNDAMENTAÇÃO TEÓRICA}

\subsection{Catalisadores internacionais da Política Nacional de Meio Ambiente}

O início da preocupação da sociedade com as questões ambientais data dos anos 60 . Nesta década, a ambientalista e bióloga americana Carson (1969) publicou seu livro "Primavera Silenciosa" com ampla repercussão, denunciando os impactos adversos negativos do uso indiscriminado de organoclorados no controle de pragas na agricultura, mais notadamente o DDT (diclorodifeniltricloroetano). Os acidentes ambientais que se seguiram, desde então, aumentaram a preocupação geral com a qualidade do meio ambiente, em especial com o ar e a água.

Posteriormente, a Conferência das Nações Unidas sobre o Meio Ambiente Humano realizada em Estocolmo, em junho de 1972, foi outro fator influenciador dos avanços da agenda ambiental em todo o mundo. Esta conferência é reconhecida como a primeira conferência das Nações Unidas centrada em questões ambientais internacionais, refletindo o crescente interesse na conservação do meio ambiente em todo o planeta e o embrião para as iniciativas de governança ambiental global, que tem se seguido desde então sobre a sustentabilidade planetária e a Agenda Verde Internacional. Na declaração final da Conferência de Estocolmo. está explícita a finitude dos recursos naturais, o impacto da atividade humana sobre o meio ambiente e a preservação do meio ambiente como condição sine qua non para a própria sobrevivência da humanidade. Por outro lado, a Conferência de Estocolmo também resultou na criação do Programa das Nações Unidas para o Meio Ambiente (PNUMA), com o intuito de coordenar os esforços globais para promover a sustentabilidade e salvaguardar o meio ambiente natural (BARROS, 2015).

Como efeito dessa Conferência, destacam-se o "Framework for Environmental Action", um plano de ação contendo 109 recomendações específicas relacionadas a assentamentos humanos, gestão de recursos naturais, poluição, aspectos educacionais e sociais do meio ambiente, desenvolvimento e as organizações internacionais (ONU, 2021). Outrossim, a declaração de direitos humanos, em seu primeiro princípio, assim expressa:

\footnotetext{
O homem tem o direito fundamental à liberdade, à igualdade e ao desfrute de condições de vida adequadas em um meio ambiente de qualidade tal que the permita levar uma vida digna e gozar de bem-estar, tendo a solene obrigação de proteger e melhorar o meio ambiente para as gerações presentes e futuras. A este respeito, as políticas que promovem ou perpetuam o apartheid, a segregação racial, a discriminação, a opressão colonial e outras formas de opressão e de dominação estrangeira são condenadas e devem ser eliminadas (ONU, 1972).
}

Por outro lado, nos princípios 8 e 9, a declaração explicita a interdependência entre preservação do meio ambiente e desenvolvimento econômico, não em oposição, mas em complementaridade, posto que, como era o pensamento dominante até o momento, no qual a degradação do meio ambiente é apenas um efeito colateral a ser aceito, em função do desenvolvimento econômico de uma nação, era a tônica das políticas das nações em todo o globo.

Outro documento fundamental e provocador para o debate sobre meio ambiente e desenvolvimento foi o Relatório Meadows. Publicado em 1972, sob o título "Os Limites do Crescimento", este estudo foi elaborado pela equipe do Massachusetts Institute of Technology (MIT), sob o patrocínio do Clube de Roma. A partir de modelos, o documento conclui que o planeta não seria capaz de suportar a pressão gerada sobre os recursos naturais, energéticos e ao aumento da poluição, mesmo tendo em conta os avanços tecnológicos, por causa do aumento de demanda oriundo do crescimento populacional (MEADOWS; RANDERS; MEADOWS, 2004).

Em 1974, o conceito de ecodesenvolvimento de Ignacy Sachs (2000), a partir de uma proposição de Maurice Strong, o então Secretário da Conferência de Estocolmo, passa a ser amplamente debatido (MONTIBELLER FILHO, 1993). A partir do termo "ecodesenvolvimento" até então utilizado, mediante a publicação do Relatório Brundtland em 1987, passou-se a utilizar globalmente a expressão "desenvolvimento 
sustentável". Desde então, o "desenvolvimento sustentável" passou a ser a inspiração às nações em busca de um crescimento que conviva suficientemente em equilíbrio com os limites planetários, em respeito ao pacto intergeracional (ONU, 1987).

\subsection{A Política Nacional do Meio Ambiente - Lei no. 6.938/1981}

As preocupações de cunho ecológico apareceram na arena nacional na década de 60 , com os movimentos de contracultura hippie, estudantis e de artistas, principalmente. Como de praxe em toda parte do globo, o Direito Ambiental surge e se fortalece pela luta social, cujo protagonismo dos movimentos populares pela defesa e conservação ambiental se dá através de associações civis ambientalistas na década de 70 (SARLET; FENSTERSEIFER, 2019). Foi nos reflexos da teoria do decrescimento, protagonizada pelo Clube de Roma, no "Relatório Meadows", publicado em 1972, sob o título "Os Limites do Crescimento" (MEADOWS; RANDERS; MEADOWS, 2004), e no mote da Conferência de Estocolmo organizada pelas Nações Unidas em 1972, que a Política Nacional do Meio Ambiente, a Lei no. 6.938 de 1981 (BRASIL, 1981) teve seu advento, mediante a assinatura do então presidente da república João Figueiredo, o último representante militar no governo.

A Lei no. 6.938 de 1981 foi responsável por introduzir o Direito Ambiental Brasileiro moderno, tal qual é conhecido nos dias de hoje. Esta lei trouxe em seu bojo não apenas a sistematização da legislação ambiental brasileira, como discriminou os "conceitos-chave, objetivos, princípios, instrumentos, etc" (SARLET; FENSTERSEIFER, 2019, p. 48). Nesse diapasão, o Brasil trouxe à lume uma legislação ambiental moderna, de vanguarda e que institui, pela primeira vez no país, "os princípios, formas e ferramentas de gestão e defesa ambiental, para atingimento do propósito da implementação do desenvolvimento sustentável no país" (MORETI; TAMIOSSO; TAMIOSSO; SWAROWSKY, 2017, p. 254).

Através desta lei, foi inaugurado o Sistema Nacional de Meio Ambiente, ou SISNAMA, e instrumentos importantes de gestão e proteção ao meio ambiente foram introduzidos ao cenário nacional, parte deles de pouco conhecimento e experiência dos brasileiros à época, mas frequentemente exigidos por instituições internacionais de financiamento de obras e infraestrutura, firmados para conter a dívida externa. De acordo com Palomares, Santos e Pietro (2018, p. 35), o "SISNAMA tem por finalidade propiciar a gestão democrática com a participação da sociedade civil, em cooperação com os entes públicos para atingir a proteção ambiental na esfera administrativa".

Outra formulação deste diploma legal, conhecido como o "Código Ambiental Brasileiro", foi "justamente reconhecer o ambiente (ou seja, seus elementos naturais e humanos ou sociais) como um bem jurídico autônomo digno de proteção" (SARLET; FENSTERSEIFER, 2019, p. 48). Outra importante contribuição da Política Nacional do Meio Ambiente foi a definição de "meio ambiente" em seu artigo $3^{\circ}$, como "o conjunto de condições, leis, influências e interações de ordem física, química e biológica, que permite, abriga e rege a vida nas diferentes formas" (BRASIL, 1981). Contudo, observa-se que a amplitude dessa legislação ambiental focava principalmente a proteção ambiental e o controle de impactos pela intervenção humana.

O patrimônio ecológico (por exemplo, a qualidade, o equilíbrio e a segurança ambientais) passou a ser considerado como um fundamento em si para justificar a regulação jurídica do uso dos recursos naturais, não havendo mais necessidade de se recorrer a outros interesses e direitos (saúde pública, ordem econômica, propriedade etc.), como se verificava de forma preponderante na legislação brasileira precedente. Além disso, com a criação do Sistema Nacional do Meio Ambiente (SISNAMA) pela Lei 6.938/81, a proteção ambiental passou a ser tratada como uma política pública de expressão nacional - uma verdadeira política de Estado -, estimulando-se a criação de órgãos ambientais especializados nas diversas esferas federativas (União, Estados, Distrito Federal e Municípios). (SARLET; FENSTERSEIFER, 2019, p. 48).

A Política nacional do meio ambiente foi um divisor de águas, pois inexistia, no país, planos de uso racional dos recursos naturais. O que existia de fato eram estratégias de diferentes âmbitos (municipal, estadual e federal), que acabavam ocasionando condutas públicas descoordenadas, além de conflitos de 
poder (MENEGUZZO, 2020). Por outro lado, as políticas públicas ambientais existentes eram setorizadas e regionalizadas (por unidades da federação), com a ausência por completo de uma política ambiental única e coerente de abrangência nacional (MENEGUZZO, 2020). Ainda conforme Meneguzzo (2020), a Lei no. 6.938/1981 institui como premissa primeira a importância institucional do Estado no que tange a manutenção do equilíbrio ecológico (BRASIL, 1981). Isso se explica, pois, internamente, eram elaborados instrumentos legais de avaliação de impactos ambientais, devido à pressão do Banco Mundial e da sociedade brasileira (MENEGUZZO, 2020). Paulo Nogueira Neto, biólogo da região de Campinas, interior do Estado de São Paulo, e mentor da Lei no. 6.938/81, em uma de suas últimas entrevistas, comenta que "A Política Nacional do Meio Ambiente fez com que, pela primeira vez, decisões sobre a matéria fossem tomadas por meio de resoluções do CONAMA, órgão colegiado, que é resultado direto da Lei 6.938/1981" (FIORI, et al., 2006).

De fato, a política nacional do meio ambiente deu prerrogativa e força ao Poder Judiciário e ao parquet para agir de forma mais independente nas ações judiciais e extrajudiciais que envolvem o meio ambiente antes mesmo da promulgação da Constituição Cidadã de 1988 (SARLET; FENSTERSEIFER, 2019, p. 49). Uma lei, seja de que tipo for, é o resultado de um passado, em cujas premissas históricas de formação está a subsunção de um fato social à norma. $O$ fenômeno da subsunção se distingue pela ação ou efeito de subsumir, isto é, incluir alguma coisa menor em algo maior, mais amplo, do geral para o específico. Configurase o fenômeno, quando o caso concreto ou fato social se enquadra à norma legal em abstrato, na adequação de uma conduta (norma-fato) à norma lógica (norma-tipo). No caso especial da Política Nacional do Meio Ambiente, ditada por um encadeamento de fatos sociais relacionados, bem como influenciada por movimentos sociais, políticos, ambientais e econômicos da época, nacionais e internacionais, teve como pressupostos as seguintes motivações, indicadas no Quadro 01:

Quadro 01. Pressupostos da Política Nacional do Meio Ambiente

\begin{tabular}{|c|c|}
\hline $\begin{array}{l}\text { Tipo de } \\
\text { Influência }\end{array}$ & Pressupostos \\
\hline \multirow[b]{2}{*}{ Econômica } & Dependência do país no capital estrangeiro e Banco Mundial. \\
\hline & $\begin{array}{l}\text { Dívida externa do Brasil crescente e com juros elevados, que forçava a novos } \\
\text { pedidos de empréstimos, dilatamento de pagamento da divida e processos de } \\
\text { reinvestimento. }\end{array}$ \\
\hline $\begin{array}{l}\text { Ambiental e } \\
\text { Econômica }\end{array}$ & $\begin{array}{l}\text { Banco Mundial passou a exigir instrumentos de gestão ambiental nos } \\
\text { empreendimentos de energia e mineração contratados pelo Brasil. }\end{array}$ \\
\hline $\begin{array}{l}\text { Ambiental e } \\
\text { Política }\end{array}$ & $\begin{array}{l}\text { Globalização e internacionalização do direito ambiental, propagando-se até o } \\
\text { Cone Sul. }\end{array}$ \\
\hline \multirow[b]{2}{*}{ Política } & $\begin{array}{l}\text { Processo de abertura e redemocratização da política brasileira com o fim do } \\
\text { regime militar. }\end{array}$ \\
\hline & $\begin{array}{l}\text { Forte tensão em ambiente institucional interno com o Clube de Roma e } \\
\text { Convenção de Estocolmo, por temor do regime militar com uma perda da } \\
\text { soberania nacional às nacões hegemônicas. }\end{array}$ \\
\hline \multirow[b]{2}{*}{ Social } & Cobrancas ambientalistas de movimentos sociais e da sociedade civil \\
\hline & $\begin{array}{l}\text { Questốes da terra e reforma agrária em pauta no país com os movimentos } \\
\text { populares e da pastoral católica }\end{array}$ \\
\hline
\end{tabular}

Fonte: Elaborado pelos autores (2021).

O enfraquecimento da ditadura militar e sua substituição pelo regime democrático estimulou, ainda, a participação popular no debate político e na adesão aos pressupostos do movimento ambientalista internacional. Tal mudança de posicionamento refletiu, inclusive, na própria Constituição Federal Brasileira de 1988, que viria alguns anos depois, inaugurar a constitucionalização da Agenda Verde internacional no ambiente interno do país.

A legislação que se seguiu após a Lei no. 6.938 de 1981 foi na mesma linha do vanguardismo ecológico e seguindo as diretrizes e orientações regidas pela Política Nacional do Meio Ambiente, ora para regulamentar 
seus dispositivos legais, ora para complementá-los, ou propagar novas leis através de diferentes institutos em prol da conservação, gestão, defesa e proteção do meio ambiente. Inclui-se nisso a própria Constituição Federal de 1988, a qual consagrou o dispositivo 225 para inaugurar o "direito e dever fundamental" ao meio ambiente equilibrado de responsabilidade de todos, sociedade civil e governo. Nesse âmbito, conforme Sarlet e Fensterseifer (2019),

\begin{abstract}
"vinculando de modo concorrente o Estado-Legislador, o Estado-Administrador e o Estado-Juiz, além, é claro, da responsabilidade ambiental - civil, administrativa e ambiental, conforme disposto no Art. 225, $\S 3^{\circ}$ - por parte da sociedade em geral, tomando por base, inclusive, o conceito amplo de poluidor trazido pelo art. $3^{\circ}$, IV, da Lei 6.938/81. Para muitos, o regime constitucional delineado na CF/1988 (art. 225 e inúmeros outros dispositivos dispersos ao longo do seu texto) estabeleceu as bases normativas para a edificação de um Direito Constitucional Ecológico, de uma Constituição Ecológica e de um modelo de Estado Democrático, Social e Ecológico de Direito. Um novo capítulo da história do Direito Ambiental brasileiro estava escrito, com a inserção da proteção ecológica entre os valores supremos da nossa ordem jurídica" (SARLET; FENSTERSEIFER, 2019, p. 49-50).
\end{abstract}

O artigo 225 da Constituição Federal expõe o direito fundamental ao meio ambiente ecologicamente equilibrado como bem de uso comum do povo, sendo este essencial para a qualidade de vida da população e dever do Poder Público e da coletividade a defesa e a preservação ambiental para as presentes e futuras gerações (BRASIL, 1988).

A "constitucionalização" da agenda da proteção do ambiente pela Constituição da República Federativa do Brasil de 1988 (art. 225) conferiu centralidade aos valores, princípios e direitos ecológicos no âmbito do ordenamento jurídico brasileiro. A consagração do objetivo e dos deveres de proteção ambiental do Estado brasileiro (em todos as esferas federativas) estabelece, de tal sorte, a expressa vinculação de todos os poderes estatais (Legislativo, Executivo e Judiciário) no sentido de agir de acordo com tal diretriz normativa, inclusive à luz de um novo modelo de Estado de Direito de feição ecológica (Estado Democrático, Social e Ecológico de Direito). Igualmente, a atribuição do status jurídico constitucional de direito fundamental ao direito ao ambiente ecologicamente equilibrado coloca os valores ecológicos no "coração" do nosso sistema jurídico, influenciando todos os ramos do ordenamento jurídico, inclusive de modo a limitar outros direitos e/ou princípios, interesses e bens jurídicos, fundamentais ou não (SARLET; FENSTERSEIFER, 2019, p. 45).

Nesse sentido, a partir da Política Nacional do Meio Ambiente, através da Carta Magna de 1988, elevase à categoria de direito fundamental da pessoa humana e de toda a coletividade o direito ambiental, assim como torna a proteção ambiental propósito fundamental do Estado de Direito Ambiental brasileiro (COELHO, 2014; LEITE, 2015; SARLET; FENSTERSEIFER, 2019) por meio de seus artigos 225, caput, $5^{\circ}$, $\S 2^{\circ}$ e 170. Assim, passa a ser um poder - dever do Poder Público como conduta positiva (de fazer) e negativa (de não fazer) de Estado, conformando a política constitucional ambiental (LEITE, 2015) ao código ambiental retratado na Política Nacional do Meio Ambiente.

Outrossim, o conceito de direitos de terceira geração já foi tema em que o Supremo Tribunal Federal se posicionou no Mandado de Segurança MS 22.164-0/SP, de relatoria do Ministro Celso de Mello, cuja decisão foi publicada em 17.11.1995'. Nesta decisão, o Supremo confirma que o direito ao meio ambiente ecologicamente equilibrado é de terceira geração (COELHO, 2014). O reconhecimento constitucional e judicial do direito ambiental como de terceira geração estabelece de per si o Estado de Direito Ambiental brasileiro (COELHO, 2014; LEITE, 2015; SARLET; FENSTERSEIFER, 2019) com a estruturação do "Direito Constitucional Ecológico, de uma Constituição Ecológica e de um modelo de Estado Democrático, Social e

1 STF. Mandado de Segurança MS 22.164-0/SP; Relator Ministro Celso de Mello (DJ 17/11/95, 39206). Disponível em: <https://stf.jusbrasil.com.br/jurisprudencia/745049/mandado-de-seguranca-ms-22164-sp>. Acesso em: 08.06.2021. 
Ecológico de Direito" (SARLET; FENSTERSEIFER, 2019, p. 45) no país.

A Lei no. 6.938/1981, logo em seu artigo $2^{\circ}$, primeira parte, estabelece os objetivos da política em âmbito nacional, quais sejam: "a preservação, melhoria e recuperação da qualidade ambiental propícia à vida", a fim de garantir os pressupostos essenciais ao "desenvolvimento socioeconômico, aos interesses da segurança nacional e à proteção da dignidade da vida humana" (BRASIL, 1981). A segunda parte ${ }^{2}$ do mesmo dispositivo integra aos objetivos elencados e os princípios que norteiam a própria política e seu advento. Chama-se a atenção para o fato de que os princípios, em sua maior parte, instauram mandamentos gerais ao Estado para o controle, planejamento, fiscalização, proteção, defesa e conservação do equilíbrio ecológico do meio ambiente no Brasil. É também através desta Lei que se define formalmente "meio ambiente", a figura do "poluidor" e o que são os "recursos ambientais":

“Art $3^{\circ}$ - Para os fins previstos nesta Lei, entende-se por: I - meio ambiente, o conjunto de condições, leis, influências e interações de ordem física, química e biológica, que permite, abriga e rege a vida em todas as suas formas; [...] IV - poluidor, a pessoa física ou jurídica, de direito público ou privado, responsável, direta ou indiretamente, por atividade causadora de degradação ambiental; V - recursos ambientais: a atmosfera, as águas interiores, superficiais e subterrâneas, os estuários, o mar territorial, o solo, o subsolo, os elementos da biosfera, a fauna e a flora" (BRASIL, 1981).

Pertinente ao art. $4^{\circ}$ seguinte, em seu inciso I, é propósito da Política Nacional do Meio Ambiente a compatibilização do desenvolvimento econômico-social com a preservação da qualidade do meio ambiente e do equilíbrio ecológico, bem como, no inciso $\mathrm{VI}$, a preservação e restauração dos recursos ambientais com vistas à sua utilização racional e disponibilidade permanente, concorrendo para a manutenção do equilíbrio ecológico propício à vida como dever do Estado, ficando o sujeito poluidor infrator, nos termos do inciso VII, obrigado a recuperar e indenizar os danos causados e, ao usuário, da contribuição pela utilização de recursos ambientais com fins econômicos (BRASIL, 1981).

Por outro lado, ressalta-se $\mathrm{O}$ artigo $5^{\circ}$ da Lei no. 6.938/1981 pelas diretrizes coordenadoras e regulamentadoras das ações conjuntas dos diversos entes federativos para tornar a existência da Política Nacional do Meio Ambiente dotada de concretude e prática na rotina do país, que, na qualidade de verdadeiro programa a ser seguido por toda a federação, estabelece:

Art. $5^{\circ}$ - As diretrizes da Política Nacional do Meio Ambiente serão formuladas em normas e planos, destinados a orientar a ação dos Governos da União, dos Estados, do Distrito Federal, dos Territórios e dos Municípios no que se relaciona com a preservação da qualidade ambiental e manutenção do equilíbrio ecológico, observados os princípios estabelecidos no art. $2^{\circ}$ desta Lei. Parágrafo único - As atividades empresariais públicas ou privadas serão exercidas em consonância com as diretrizes da Política Nacional do Meio Ambiente (BRASIL, 1981).

Já no âmbito do SISNAMA, a Lei em comento estabelece em seu artigo $6^{\circ}$, os órgãos e entidades,

\footnotetext{
${ }^{2}$ Art. $2^{\circ}$ A Política Nacional do Meio Ambiente tem por objetivo a preservação, melhoria e recuperação da qualidade ambiental propícia à vida, visando assegurar, no País, condições ao desenvolvimento socioeconômico, aos interesses da segurança nacional e à proteção da dignidade da vida humana, atendidos os seguintes princípios: I - ação governamental na manutenção do equilíbrio ecológico, considerando o meio ambiente como um patrimônio público a ser necessariamente assegurado e protegido, tendo em vista o uso coletivo; II - racionalização do uso do solo, do subsolo, da água e do ar; III - planejamento e fiscalização do uso dos recursos ambientais; IV - proteção dos ecossistemas, com a preservação de áreas representativas; $V$ - controle e zoneamento das atividades potencial ou efetivamente poluidoras; VI - incentivos ao estudo e à pesquisa de tecnologias orientadas para o uso racional e a proteção dos recursos ambientais; VII - acompanhamento do estado da qualidade ambiental; VIII - recuperação de áreas degradadas; IX - proteção de áreas ameaçadas de degradação; X - educação ambiental a todos os níveis de ensino, inclusive a educação da comunidade, objetivando capacitá-la para participação ativa na defesa do meio ambiente (BRASIL, 1981).
} 
bem como fundações públicas que serão responsáveis por salvaguardar a proteção e melhoria da qualidade ambiental, que essencialmente são os indicados no Quadro 2:

Quadro 2. Órgãos e instituições públicas de proteção e melhoria ambiental na Política Nacional do Meio Ambiente

\begin{tabular}{|c|c|}
\hline Orqão ou instituicão pública & Funcão \\
\hline $\begin{array}{l}\text { Conselho Nacional do Meio Ambiente } \\
\text { (CONAMA), art. } 6^{\circ} \text {, inciso II, Lei } n^{\circ} .6 .938 / 1981 .\end{array}$ & $\begin{array}{l}\text { Orgão consultivo e deliberativo, cuja finalidade é } \\
\text { assessorar, estudar e propor ao Governo, } \\
\text { diretrizes de políticas governamentais para o } \\
\text { meio ambiente e os recursos naturais e deliberar, } \\
\text { no âmbito de sua competência, sobre normas e } \\
\text { padrões compatíveis com o meio ambiente } \\
\text { ecologicamente equilibrado e essencial à sadia } \\
\text { qualidade de vida. Ademais, é o CONAMA } \\
\text { responsável por estabelecer, mediante proposta } \\
\text { do IBAMA, normas e critérios para o } \\
\text { licenciamento de atividades efetiva ou } \\
\text { potencialmente poluidoras, a ser concedido } \\
\text { pelos Estados e supervisionado pelo IBAMA (art. } \\
8^{\circ} \text { inciso I, Lei } n^{\circ} \text {. } 6.938 / 1981 \text { ). }\end{array}$ \\
\hline $\begin{array}{l}\text { Instituto Brasileiro do Meio Ambiente e dos } \\
\text { Recursos Naturais Renováveis (IBAMA) e } \\
\text { Instituto Chico Mendes de Conservação da } \\
\text { Biodiversidade (ICMBio), art. } 6^{\circ} \text {, inciso VI, Lei } \mathrm{n}^{\circ} \text {. } \\
6.938 / 1981 \text {. }\end{array}$ & $\begin{array}{l}\text { São os órgãos executores, cuja finalidade é } \\
\text { executar e fazer executar a política e as diretrizes } \\
\text { governamentais fixadas para o meio ambiente, } \\
\text { de acordo com as respectivas competências. O } \\
\text { art. } 11 \text { estabelece que é função do IBAMA propor } \\
\text { ao CONAMA normas e padrões para } \\
\text { implantação, acompanhamento e fiscalização do } \\
\text { licenciamento previsto no artigo anterior, além } \\
\text { das que forem oriundas do próprio CONAMA. }\end{array}$ \\
\hline
\end{tabular}

Fonte: Informações contidas na Lei no. 6.938/1981 e organizadas pelos autores.

Ainda com relação aos órgãos executores, consultivos e deliberativos, o artigo $6^{\circ}$ da Política Nacional do Meio Ambiente estabelece, nos parágrafos $1^{\circ}$ e $2^{\circ}$, as competências dos demais entes federados:

$\S 1^{\circ}$ Os Estados, na esfera de suas competências e nas áreas de sua jurisdição, elaborarão normas supletivas e complementares e padrões relacionados com o meio ambiente, observados os que forem estabelecidos pelo CONAMA.

$\S 2^{\circ}$ Os Municípios, observadas as normas e os padrões federais e estaduais, também poderão elaborar as normas mencionadas no parágrafo anterior (BRASIL, 1981).

Denota-se que as competências dos estados e municípios são supletivas e não concorrentes, pois a Política Nacional do Meio Ambiente organizou e sistematizou o universo complexo e transdisciplinar das relações humanas com o meio ambiente através do Estado, harmonizadas coerentemente em suas diversas instâncias de poder.

Outra inovação trazida pela Lei no. 6.938/1981 diz respeito à definição de "degradação ambiental" e aos instrumentos da Política Nacional do Meio Ambiente, preconizados em seu art. $9^{\circ} \mathrm{e}$ incisos. Com relação à degradação ambiental, a mesma lei a define, em seu art. $3^{\circ}$, inciso $\mathrm{Il}$, como a alteração adversa das características do meio ambiente (BRASIL, 1981). Vale lembrar que, de acordo com a Resolução CONAMA $n^{\circ}$ 01/86, degradação ambiental está diretamente relacionada com impacto ambiental negativo, no qual, considera-se como degradação da qualidade ambiental aquela ocasionada pela atividade humana (BRASIL, 1986). 
Dessa forma, a política nacional define como "degradação da qualidade ambiental" o resultado traduzido como alteração adversa das características naturais do meio ambiente (inciso II do art. $3^{\circ}$, Lei no. 6.938/1981) e "poluição" (inciso III do art. $3^{\circ}$, Lei no. 6.938/1981) como sendo a degradação da qualidade ambiental, que seja resultante de atividades que, direta ou indiretamente, resultem em: a) prejuízos à saúde, segurança e bem-estar da população; b) condições adversas às atividades sociais e econômicas; c) impactos negativos que desfavoreçam a biota; d) efeitos desequilibradores às condições estéticas ou sanitárias do meio ambiente; e) lançamento de matérias ou energia em desacordo com os padrões ambientais estabelecidos (BRASIL, 1981).

Pertinente aos instrumentos de gestão e proteção ambiental, a política os relaciona em seu art. $9^{03}$. A função técnica dos instrumentos de gestão ambiental é de mitigar riscos e amortecer eventuais danos, cuja amplitude e magnitude sejam drásticas a ponto de impactar o meio ambiente com custos externos ou externalidades. Portanto, seu propósito é regulamentar atividades que envolvam, direta ou indiretamente, a natureza, sendo necessária a preservação, melhoria e recuperação da qualidade ambiental (BARROS, et al., 2012). Os incisos III e IV do artigo $9^{\circ}$, especificamente, indicam os instrumentos da Avaliação de Impacto Ambiental (AIA) e do Licenciamento Ambiental para a gestão contumaz, aperfeiçoados posteriormente através da Resolução CONAMA no. 237 de 19 de dezembro de 1997 (BRASIL, 1997), ao passo que abre caminho para a Política do Sistema Nacional de Unidades de Conservação da Natureza - SNUC (BRASIL, 2000) e o instituto da compensação ambiental em operação no país. Acima de tudo, a Política Nacional do Meio Ambiente se traduz em uma lei de vanguarda, introduzindo o meio ambiente como direito e dever de todos na categoria de bem comum e coletivo (JONAS, 2006; SOUZA, 2010).

Ademais, esta política estabelece, dentre os meios de gestão e defesa ambiental do art. $9^{\circ}$, a participação popular (PALOMARES; SANTOS; PIETRO, 2018) como meio de gestão ambiental no Brasil. O CONAMA, como órgão de consulta e deliberação do SISNAMA, possuía, desde sua origem, o conselho composto por "colegiado representativo de cinco setores" (PALOMARES; SANTOS; PIETRO, 2018, p. 36), com representantes da sociedade civil em paridade. Conforme o art. $5^{\circ}$, inciso VIII do Decreto no. 99.274/90, representantes da sociedade civil deveriam fazer parte também do Plenário do CONAMA (PALOMARES; SANTOS; PIETRO, 2018).

Em âmbito nacional, a Política Nacional do Meio Ambiente inaugurou ab initio, seja através do SISNAMA (BRASIL, 1981), seja através do CONAMA (BRASIL, 1986), o estabelecimento da participação popular em pleno regime militar (PALOMARES; SANTOS; PIETRO, 2018; SOUZA; SILVAFILHO; MASTRODI NETO, 2020) como gestão e governança compartilhada (CONTI, et al., 2019) de direito da sociedade civil em paridade com representantes do governo e do mercado, em verdadeiro exercício da cidadania em um ambiente institucional interno que já procurava avançar na democracia ante o enfraquecimento do regime militar.

A participação popular foi implantada em cooperação com os entes públicos para a proteção ambiental na esfera administrativa, que a própria Lei no. 6.938/1981 e resoluções normativas do CONAMA inaugura por câmaras paritárias e audiências públicas. Ademais, com base na Política Ambiental do Meio Ambiente, em 1985, é sancionada a Lei da Ação Civil Pública (BRASIL, 1985), a qual disciplina a medida como instrumento

\footnotetext{
${ }^{3}$ Art $9^{\circ}$ - São instrumentos da Política Nacional do Meio Ambiente: I - o estabelecimento de padrões de qualidade ambiental; II - o zoneamento ambiental; III - a avaliação de impactos ambientais; IV - o licenciamento e a revisão de atividades efetiva ou potencialmente poluidoras; $V$ - os incentivos à produção e instalação de equipamentos e a criação ou absorção de tecnologia, voltados para a melhoria da qualidade ambiental; VI - a criação de espaços territoriais especialmente protegidos pelo Poder Público federal, estadual e municipal, tais como áreas de proteção ambiental, de relevante interesse ecológico e reservas extrativistas; VII - o sistema nacional de informações sobre o meio ambiente; VIII - o Cadastro Técnico Federal de Atividades e Instrumentos de Defesa Ambiental; IX - as penalidades disciplinares ou compensatórias ao não cumprimento das medidas necessárias à preservação ou correção da degradação ambiental; $X$ - a instituição do Relatório de Qualidade do Meio Ambiente, a ser divulgado anualmente pelo Instituto Brasileiro do Meio Ambiente e Recursos Naturais Renováveis - IBAMA; XI - a garantia da prestação de informações relativas ao Meio Ambiente, obrigando-se o Poder Público a produzi-las, quando inexistentes; XII - o Cadastro Técnico Federal de atividades potencialmente poluidoras e/ou utilizadoras dos recursos ambientais; XIII - instrumentos econômicos, como concessão florestal, servidão ambiental, seguro ambiental e outros (BRASIL, 1981).
} 
processual específico para a defesa do meio ambiente, ao passo que estabelece a Lei de Crimes Ambientais (BRASIL, 1998) com base no art. 40 e incisos da política.

\section{METODOLOGIA}

Nesta pesquisa, foi utilizada a abordagem qualitativa, isto porque, como proposto por Gil (2008, p. 114) "estamos buscando melhor compreensão do problema, gerar hipóteses e fornecer elementos para coleta de dados" para estudos futuros. A pesquisa também pode ser classificada como exploratória, pois se propõe gerar ideias e esclarecer fatos sobre a Política Nacional do Meio Ambiente em um contexto maior de viés político-econômico desde seu advento, em 1981, até a atualidade, com a ascendência de reversões políticas e esvaziamento desde o ano de 2012, arrefecendo-se principalmente a partir de 2018 com a subida ao poder de governo de viés conservador neoliberal.

Essa pesquisa, de cunho qualitativo e exploratório, envolveu levantamento bibliográfico, com o propósito de conhecer as pesquisas já realizadas e os problemas que não foram pesquisados, possibilitando, então, novas colocações acerca da Política Nacional do Meio Ambiente e sua jornada desde sua publicação.

Por essa razão, a análise dos dados levantados na pesquisa foi realizada pelo método de abordagem sistêmico-complexo. Carvalho e Fávero (2020) entendem que a teoria da complexidade tem suas origens na teoria geral de sistemas proposta por Ludwig Von Bertalanffy (2010), e no trabalho de Weiner sobre a cibernética (1940/50). Ideias surgidas com estes pensadores, como tratar os problemas dos seres humanos como "típicos de sistemas", são importantes na teoria da complexidade. Morin (2000) argumenta que a teoria da complexidade procura superar a abordagem científica tradicional, a qual divide o conhecimento em disciplinas e separa fenômenos complexos em partes, ignorando, desta forma, a totalidade sistêmica dessas realidades complexas.

A compreensão da Política Nacional do Meio Ambiente - Lei no. 6.938, de 31 de agosto de 1981 exige pensar o contexto e singularidades de seu advento na sociedade brasileira em meio ao regime militar, bem como sua jornada no sentido de formar o contexto principiológico e valorativo da lei que, até a atualidade, significa o nascimento do Direito Ambiental Brasileiro e do Estado Ambiental de Direito no país.

\section{RESULTADOS}

\subsection{Panorama atual}

As políticas ambientais envolvem uma gama variável de personagens, cujas relações se tornam tempestuosas sempre que o capital subverte a lógica da ética do cuidado e da solidariedade intergeracional (BOFF, 2009; JONAS, 2006), afinal a "ética da responsabilidade tem como base valores de uma ordem institucionalizada" (BARROS, 2012, p. 6).

Nesse sentido, ao buscar promover a sustentabilidade nas interações socioambientais, a política ambiental permeia, questiona e mobiliza diversas áreas de conhecimento, ideologias, crenças, atores, fronteiras geográficas, atividades humanas, setores econômicos e subsistemas de políticas públicas, conforme Morin (2000), Leite (2015) e Capra e Matei (2018). A Agenda Verde Internacional e os movimentos populares no Brasil pela democratização da ordem interna, conforme detalhado nos tópicos anteriores, colaborou em promover uma maior fluidez no debate legislativo até a final aprovação e publicação da Lei no. 6.938/1981.

Segundo estudos de Ferreira e Salles (2017, p. 1), a "política ambiental praticada em um país indica o modo como os recursos naturais são utilizados e adequados para o desenvolvimento de atividades econômicas que geram impactos potencialmente degradantes". Em verdade, a Política Nacional do Meio Ambiente foi e continua sendo o Código Ambiental Brasileiro, que organizou, sistematizou e alicerçou as demais políticas, leis e normas socioambientais que foram surgindo a partir de 1981, tendo sido recepcionada em sua íntegra 
pela Constituição Federal de 1988 nos artigos $225^{4}$ e $170^{5}$ (FERREIRA; SALLES, 2017).

Ainda, Ferreira e Salles (2017) ressaltam que a Constituição replicou os instrumentos de gestão, proteção e conservação ambiental indicados no art. $9^{\circ}$ da Lei no. 6.938/1981. Portanto, a Carta Política recepcionou a Política Nacional do Meio Ambiente em sua íntegra, seus princípios, diretrizes e instrumentos de gestão, proteção e conservação do meio ambiente (SARLET; FENSTERSEIFER, 2019). Com essa abordagem, em reforço à Política Nacional, a Constituição Federal de 1988 confere o poder - dever (SARLET; FENSTERSEIFER, 2019) às três esferas do Poder Público para proteção, conservação e defesa de um meio ambiente equilibrado, bem como a fiscalização e condenação dos agentes que pratiquem condutas lesivas, positivas ou negativas, ao meio ambiente (MORETI; TAMIOSSO; TAMIOSSO; SWAROWSKY, 2017; SARLET; FENSTERSEIFER, 2019).

Dessa forma, a Política Nacional do Meio Ambiente, ao corroborar com os artigos 170 e 225 da Carta Magna de 1988, inaugura com ela o "Direito Constitucional Ecológico", a "Constituição Ecológica" e o modelo de "Estado Democrático, Social e Ecológico de Direito" (SARLET; FENSTERSEIFER, 2019, p. 45), em um verdadeiro Estado de Direito Ambiental no país (LEITE, 2015). Em retrospectiva histórica desde a publicação da Política Nacional do Meio Ambiente como diretriz de Código Ambiental no país, em que prevaleceram seus princípios corroborados pelos artigos 170 e 225 da Carta Política (BRASIL, 1988), o país foi palco de leis e normativas ambientais (BORGES; REZENDE; PEREIRA, 2009) que, a despeito da longa jornada necessária até suas publicações, mais de 38 leis federais foram aprovadas e vigoraram no país até então. A seguir, no Quadro 3, expõe-se, exemplificadamente, esse compêndio próprio de codex ambiental, sancionadas por efeito da Política Nacional de Meio Ambiente em 1981:

\footnotetext{
${ }^{4}$ Art. 225. Todos têm direito ao meio ambiente ecologicamente equilibrado, bem de uso comum do povo e essencial à sadia qualidade de vida, impondo-se ao Poder Público e à coletividade o dever de defendê-lo e preservá-lo para as presentes e futuras gerações. $\$ 1^{\circ}$ Para assegurar a efetividade desse direito, incumbe ao Poder Público: I- preservar e restaurar os processos ecológicos essenciais e prover o manejo ecológico das espécies e ecossistemas; II- preservar a diversidade e a integridade do patrimônio genético do País e fiscalizar as entidades dedicadas à pesquisa e manipulação de material genético; [...] IV- exigir, na forma da lei, para instalação de obra ou atividade potencialmente causadora de significativa degradação do meio ambiente, estudo prévio de impacto ambiental, a que se dará publicidade; V- controlar a produção, a comercialização e o emprego de técnicas, métodos e substâncias que comportem risco para a vida, a qualidade de vida e o meio ambiente; VI- promover a educação ambiental em todos os níveis de ensino e a conscientização pública para a preservação do meio ambiente; [...] $\S 3^{\circ}$ As condutas e atividades consideradas lesivas ao meio ambiente sujeitarão os infratores, pessoas físicas ou jurídicas, a sanções penais e administrativas, independentemente da obrigação de reparar os danos causados[...] (BRASIL, 1988).

${ }^{5}$ Art.170. A ordem econômica, fundada na valorização do trabalho humano e na livre iniciativa, tem por fim assegurar a todos uma existência digna, conforme os ditames da justiça social, observados os seguintes princípios: III- função social da propriedade; [...] VI - defesa do meio ambiente, inclusive mediante tratamento diferenciado conforme o impacto ambiental dos produtos e serviços e de seus processos de elaboração e prestação; [...] (BRASIL, 1988).
} 
Quadro 3 - Principais leis e normas ambientais brasileiras após Política Nacional do Meio Ambiente

Política Nacional do Meio Ambiente - Lei nº.938, de 31 de agosto de 1981

\begin{tabular}{|c|c|}
\hline Lei $n^{0} 7.347 / 1985$ & $\begin{array}{l}\text { Disciplina a ação civil pública de responsabilidade por danos causados ao meio- } \\
\text { ambiente, ao consumidor, a bens e direitos de valor artístico, estético, histórico, } \\
\text { turísticoe dá outras providências. }\end{array}$ \\
\hline Lei $n^{0} 7.661 / 1988$ & $\begin{array}{l}\text { Como parte integrante da Política Nacional para os Recursos do Mar - PNRM e } \\
\text { Política Nacional do Meio Ambiente - PNMA, fica instituído o Plano Nacional de } \\
\text { Gerenciamento Costeiro - PNGC. }\end{array}$ \\
\hline
\end{tabular}

\section{Constituição Federal Brasileira de 1988}

\begin{tabular}{|c|c|}
\hline Lei nº 7.735/1989 & $\begin{array}{l}\text { Dispõe sobre a extinção de órgão e de entidade autárquica, cria o Instituto } \\
\text { Brasileiro do Meio Ambiente e dos Recursos Naturais Renováveis e dá outras } \\
\text { providências (Lei do IBAMA) }\end{array}$ \\
\hline Lei nº 7.802/1989 & $\begin{array}{l}\text { Dispõe sobre a pesquisa, a experimentação, a produçẫo, a embalagem e } \\
\text { rotulagem, o transporte, o armazenamento, a comercialização, a propaganda } \\
\text { comercial, a utilização, a importação, a exportação, o destino dos resíduos e } \\
\text { embalagens, o registro, a classificação, o controle, a inspeção e a fiscalização } \\
\text { de agrotóxicos. }\end{array}$ \\
\hline Lei n $7.805 / 1989$. & $\begin{array}{l}\text { Lei da Exploração Mineral: altera o Decreto-Lei } n^{\circ} 227 \text {, de } 28 \text { de fevereiro de } \\
1967 \text {, cria o regime de permissão de lavra garimpeira, extingue o regime de } \\
\text { matrícula. }\end{array}$ \\
\hline Lei n'8.171/1991 & Dispóe sobre a política agrícola. \\
\hline Lei $n^{0} 9.433 / 1997$ & $\begin{array}{l}\text { Institui a Política Nacional de Recursos Hídricos e cria o Sistema Nacional de } \\
\text { Gerenciamento de Recursos Hídricos. }\end{array}$ \\
\hline Lei $n^{0} 9.605 / 1998$ & $\begin{array}{l}\text { Dispõe sobre as sançôes penais e administrativas derivadas de condutas e } \\
\text { atividades lesivas ao meio ambiente (Lei dos Crimes Ambientais). }\end{array}$ \\
\hline Lei $n^{\circ} 9.984 / 2000$ & $\begin{array}{l}\text { Dispồe sobre a criação da Agência Nacional de Aguas e Saneamento Básico } \\
\text { (ANA) }\end{array}$ \\
\hline Lei $n^{\circ} 9.985 / 2000$ & Institui o Sistema Nacional de Unidades de Conservação da Natureza. \\
\hline Lei ${ }^{\circ}-295 / 2001$ & Dispõe sobre a Política Nacional de Conservação e Uso Racional de Energia. \\
\hline $\begin{array}{l}\text { Lei } n^{\circ} \\
10.308 / 2001\end{array}$ & $\begin{array}{l}\text { Dispõe sobre a seleção de locais, a construção, o licenciamento, a operação, a } \\
\text { fiscalizacão, os custos, a indenização, a responsabilidade civil e as garantias } \\
\text { referentes aos depósitos de rejeitos radioativos, e dá outras providências. }\end{array}$ \\
\hline $\begin{array}{l}\text { Lei no } \\
10.711 / 2003\end{array}$ & $\begin{array}{l}\text { Dispõe sobre o Sistema Nacional de Sementes e Mudas e dá outras } \\
\text { providências. }\end{array}$ \\
\hline $\begin{array}{l}\text { Lei } \mathrm{n}^{\circ} \\
10.650 / 2003\end{array}$ & $\begin{array}{l}\text { Dispõe sobre o acesso público aos dados e informaçốes existentes nos órgấos } \\
\text { e entidades integrantes do SISNAMA. }\end{array}$ \\
\hline $\begin{array}{l}\text { Lei } \mathrm{n}^{\circ} \\
11.105 / 2005\end{array}$ & Dispõe sobre a Política Nacional de Biossegurança - PNB. \\
\hline Lei $n^{\circ} 11284 / 2006$ & $\begin{array}{l}\text { Dispôe sobre a gestâo de florestas públicas para a produçấo sustentável; cria o } \\
\text { Fundo Nacional de Desenvolvimento Florestal - FNDF (Lei de Gestão de } \\
\text { Florestas Públicas) }\end{array}$ \\
\hline $\begin{array}{l}\text { Lei no } \\
11.326 / 2006\end{array}$ & $\begin{array}{l}\text { Estabelece as diretrizes para a formulação da Política Nacional da Agricultura } \\
\text { Familiar e Empreendimentos Familiares Rurais. }\end{array}$ \\
\hline Lei $\mathrm{n}^{\circ}$ & $\begin{array}{l}\text { Dispôe sobre a utilizaçâo e proteçâo da vegetaçâo nativa do Bioma Mata } \\
\text { Atlântica. }\end{array}$ \\
\hline Lei $\mathrm{n}^{\circ} \mathrm{-}$ & Estabelece a Política Nacional de Saneamento Básico. \\
\hline Lei $\mathrm{n}^{\circ}$ & $\begin{array}{l}\text { Dá nova redação a dispositivos das Leis nos } 9.636 \text {, de } 15.05 .1998 \text {, prevế } \\
\text { medidas voltadas à regularização fundiária de interesse social em imóveis da } \\
\text { União. }\end{array}$ \\
\hline
\end{tabular}

Fonte: dados obtidos nos sítios eletrônicos do Planalto (www.planalto,gov.br) e organizados pelos autores (2021). 
CRISE AMBIENTAL E A DESNATURAÇÃO DA POLÍTICA NACIONAL DO MEIO AMBIENTE NO BRASIL Luciana Lima Domingues de Souza, Fernando Zanatta, Diego de Melo Conti, Cândido Ferreira da Silva Filho

\begin{tabular}{|c|c|}
\hline $\begin{array}{l}\text { Lei }^{\circ} \\
11.516 / 2007\end{array}$ & $\begin{array}{l}\text { Dispốe sobre a criação do Instituto Chico Mendes de Conservação da } \\
\text { Biodiversidade - Instituto Chico Mendes. }\end{array}$ \\
\hline $11.794 / 2008$ & $\begin{array}{l}\text { Regulamenta o inciso VII } \S 1^{\circ} \text { art. } 225 \text { da CF/88, estabelecendo procedimentos } \\
\text { para_aso científico de animais. }\end{array}$ \\
\hline Lei $n^{\circ}$ & Institui a Política Nacional sobre Mudança do Clima. \\
\hline Lei no & $\begin{array}{l}\text { Dispôe sobre a regularizaçâo fundiária das ocupaçôes incidentes em terras } \\
\text { situadas em áreas da Uniấo,no âmbito_da Amazônia Legal. }\end{array}$ \\
\hline $12.114 / 2009$ & Cria o Fundo Nacional sobre Mudança do Clima. \\
\hline Lei $n^{\circ}$ & $\begin{array}{l}\text { Dispōe sobre a Política Nacional de Desenvolvimento Sustentável da } \\
\text { Aguicultura_e_da_Pesca, regula as atividades pesqueiras. }\end{array}$ \\
\hline Lei n ${ }^{\circ}$ & $\begin{array}{l}\text { Institui a Política Nacional de Assistếncia Técnica e Extensão Rural para a } \\
\text { Agricultura Familiar e Reforma Agrária - PNATER. }\end{array}$ \\
\hline Lei $n^{\circ}$ & Institui a Política Nacional de Resíduos Sólidos. \\
\hline Lei ${ }^{\circ}$ & $\begin{array}{l}\text { Regulamenta os arts. } 182 \text { e } 183 \text { CF } / 88 \text {, estabelece diretrizes gerais da política } \\
\text { urbana e dá outras providências (Estatuto da Cidade) }\end{array}$ \\
\hline Lei $n^{\circ}$ & $\begin{array}{l}\text { Estabelece a Política Nacional de Segurança de Barragens e cria o Sistema } \\
\text { Nacional de Informacões sobre Sequrança Be Barragens. }\end{array}$ \\
\hline Lei $\mathrm{n}^{\circ}$ & $\begin{array}{l}\text { Institui o Programa de Apoio à Conservaçấo Ambiental e o Programa de } \\
\text { Fomento às Atividades Produtivas Rurais. }\end{array}$ \\
\hline $\begin{array}{l}\text { Lei Complementar } \\
\mathrm{n}^{\circ} 140 / 2011\end{array}$ & $\begin{array}{l}\text { Fixa normas, nos termos dos incisos III, Vll e vill do caput e parágrafo único do } \\
\text { art. } 23 \mathrm{CF} / 88 \text {, para cooperação entre União, Estados, Distrito Federal e } \\
\text { Municípios nas aç̃os administrativas decorrentes do exercício da competência } \\
\text { comum relativas à proteção das paisagens naturais notáveis, proteção do meio } \\
\text { ambiente, combate à poluição e preservacão das florestas, fauna e flora. }\end{array}$ \\
\hline Dec $n^{\circ}$ & Institui a Política Nacional de Agroecologia e Produção Orgânica. \\
\hline Lei $\mathrm{n}^{\circ}$ & $\begin{array}{l}\text { Dispóe sobre a proteçấo da vegetaçấ nativa (Novo Código Florestal } \\
\text { Brasileiro). }\end{array}$ \\
\hline $\begin{array}{l}\text { Lei } n^{\circ} \\
13.123 / 2015\end{array}$ & $\begin{array}{l}\text { Regulamenta a Convenção sobre Diversidade Biológica, promulgada pelo } \\
\text { Decreto } n^{\circ} 2.519 \text {, de } 16.03 .1998 \text {; dispõe sobre o acesso ao patrimônio } \\
\text { genético, proteção e acesso ao conhecimento tradicional associado e repartição } \\
\text { de benefícios. }\end{array}$ \\
\hline $\begin{array}{l}\text { Lei } n^{\circ} \\
13.153 / 2015\end{array}$ & $\begin{array}{l}\text { Institui a Política Nacional de Combate à Desertificação e Mitigaçâo dos Efeitos } \\
\text { da Seca e seus instrumentos; criação da Comissão Nacional de Combate à } \\
\text { Desertificacão. }\end{array}$ \\
\hline $\begin{array}{l}\text { Lei } \mathrm{n}^{\circ} \\
13.576 / 2017\end{array}$ & Dispõe sobre a Política Nacional de Biocombustíveis (RenovaBiol). \\
\hline $\begin{array}{l}\text { Lei } n^{\circ} \\
13.668 / 2018\end{array}$ & $\begin{array}{l}\text { Dispōe sobre a destinação e a aplicação dos recursos de compensação } \\
\text { ambiental e contratação de pessoal por tempo determinado pelo Ibama e } \\
\text { Instituto Chico Mendes de Conservação da Biodiversidade (Instituto Chico } \\
\text { Mendes). }\end{array}$ \\
\hline $\begin{array}{l}\text { Lei }^{\circ} \\
14.119\end{array}$ & Política Nacional de Pagamento por Serviços Ambientais. \\
\hline
\end{tabular}

De acordo com o Quadro 3, verifica-se o quão singular é a influência das diretrizes e princípios da política nacional ambiental nas mais de 38 leis que foram publicadas subsequentemente, no período de 1981 a 2021, sem levar em consideração as centenas de resoluções e normativas do CONAMA (BORGES; REZENDE; PEREIRA, 2009), além de legislações e normativas estaduais e municipais (MORETI; TAMIOSSO; TAMIOSSO; SWAROWSKY, 2017) acerca do tema. Com a Constituição Federal promulgada em 1988, em seu Capítulo VI - Do Meio Ambiente, artigo 225, além dos princípios da precaução e da prevenção, o princípio da solidariedade intergeracional e o princípio da sustentabilidade (CIRNE, 2017; COELHO; ARAÚJO, 2010), inaugura-se no país uma série de leis e normas em prol do desenvolvimento sustentável e do Estado de Direito Ambiental no país (CIRNE, 2017; LEITE, 2015; MORETI; TAMIOSSO; TAMIOSSO; SWAROWSKY, 2017; SARLET; FENSTERSEIFER, 2019). 
Foram necessários 40 anos para que esse conjunto de leis e normativas pontilhassem o cenário sociopolítico e econômico do país. Alguns estudiosos nomeiam as razões de tal demora, basicamente, por conta de dois motivos principais. Como primeiro motivo, a crise econômica que se arrastou durante toda a década de 80 e 90 em um cenário inflacionário e de grande dívida pública, atrasando o input de investimentos públicos em obras de infraestrutura e na indústria nacional (FERREIRA; SALLES, 2017). A título de segundo motivo, relatam a ausência de aparelhagem, perfil e contingente humano técnico dos órgãos governamentais à disposição da política ambiental no país (FERREIRA; SALLES, 2017, p.13). No entanto, a Lei no. 6.938/1981 (BRASIL, 1981) tem sofrido impactos desde a atualização do Código Florestal de 2012 (BRASIL, 2012) que, paulatinamente, vem enfraquecendo as políticas públicas socioambientais como um todo no país. Mais recentemente, após o último pleito eleitoral de 2018, o processo de desmonte das políticas públicas ambientais tem sido intenso, acelerado e deflagrado, em um movimento que começa pelas leis e políticas resultantes da Lei no. 6.938/1981, através do que que parece ser um franco processo de desnaturação da Política de 1981 (BRASIL, 1981).

\subsection{A "nova velha" política ruralista conservadora}

O Brasil atravessa um período marcado por negacionismo da ciência (FERNANDES, et al., 2017), revogação de políticas públicas e leis federais, exclusão da participação da sociedade civil nos fóruns a que detinha assento aos seus representantes (LEVIS, et al., 2020), bem como aumento de tensão e conflitos sociais e extremismo políticos (FERRANTE; FEARNSIDE, 2020).

Em paralelo, a sociedade civil tem acompanhado o aumento dos índices de desmatamento, incêndio e invasão de áreas de proteção pelo garimpo e extração de recursos naturais dos biomas da Amazônia, Cerrado e Mata Atlântica (FONSECA-MORELLO, et al., 2017), além de facilitação de acesso à terra na Amazônia Legal aos latifundiários monocultores da soja, cana e pasto (CARVALHO; DOMINGUES; HORRIDGE, 2017; MELLO-THÉRY, 2019; SAUER; LEITE, 2012), seguido de cenas de violência e mordaça (FERRANTE; FEARNSIDE, 2020).

Autores como Meneguzzo (2020, p. 82) afirmam que "[...] passadas aproximadamente quase quatro décadas de sua promulgação, a mesma ainda serve como diretriz no tocante a relação existente entre uso dos recursos naturais, qualidade ambiental e conservação da natureza". Contudo, evidências mostram que a Política Nacional do Meio Ambiente (BRASIL, 1981) tem sido objeto de reiteradas intervenções do Poder Executivo de forma indireta, através de revogações de leis e resoluções que a efetivam, como que por efeito de borda ${ }^{6}$, causando sua desnaturação prematura ${ }^{7}$ e morte lenta. De 1981 a 2012, ou seja, do advento da Política Nacional do Meio Ambiente até pouco antes do Código Florestal (BRASIL, 2012) entrar em vigor, havia no Brasil a observância das leis ambientais no que é chamado, até hoje, do período do Estado de Direito Ambiental (CIRNE, 2017; FERREIRA; SALLES, 2017; LEITE, 2015; MORETI; TAMIOSSO; TAMIOSSO; SWAROWSKY, 2017; SARLET; FENSTERSEIFER, 2019).

Pesquisadores como Borinelli, Gallassi, Mostagi e Melan (2019) visualizam o retrocesso normativo

\footnotetext{
${ }^{6}$ Efeito de borda, em permacultura, é o processo de morte lenta de extratos florestais das bordas de mata fragmentada, quando sujeitos a desequilíbrios climáticos, parasitas, outros elementos biológicos e intervenções antrópicas. $\mathrm{O}$ resultado desse processo é o efeito da borda se instalar também nos indivíduos remanescentes, podendo extinguir toda a mata. "Só havia vestígios de suas bordas externas. Toda a parte interna já havia virado húmus - um claro indício de que o tronco provavelmente foi derrubado há 400 ou 500 anos" (WOHLLEBEN, 2017, p.7, Edição Kindle).

${ }^{7}$ Aplicado analogamente, a desnaturação constitucional ou infraconstitucional ocasiona a perda das características de essência do objeto. No dizer de Kreuz (2020, p. 264): "Desnaturação significa perda da natureza, das características próprias de um elemento, com sua descaracterização ou desconfiguração. A imposição gradual de mudanças no sentido da Constituição, tanto pela alteração de pressupostos democráticos quanto por inovações em matéria de proteção de direitos sociais, desnatura o texto constitucional e o descaracteriza por completo. Um Estado que pretendia instituir um ideal de proteção de direitos passa a considerá-los "entraves" ao desenvolvimento, "custosos" demais para um modelo estatal neoliberal".
} 
ambiental intensificado a partir de 2010. A data exata de início ou de arrefecimento no reconhecimento da Política Nacional do Meio Ambiente e do sistema constitucional ambiental, em verdade, não alteram o panorama de desnaturação da política, inobservação dos dispositivos constitucionais ambientais e, por consequência, de desmonte de leis e políticas públicas socioambientais do país.

Segundo Lima e Garcia (2014), os grupos oligárquicos do agrobusiness se uniram aos conservadores, que provocou o enaltecimento da vertente neoliberal, em que o papel do Estado, já diminuído e ausente, derroga o poder-dever ao mercado que passa a, em tese, ser os novos curadores dos direitos socioambientais no país, "fazendo com que eles gradualmente se dissipem" (LIMA; GARCIA, 2014, p.277). Há aqui também um poder de desnaturação constitucional, indiretamente, ao passo que retira do Estado o poder-dever conferido pela Carta Magna (BRASIL, 1988) para proteção, conservação e defesa de um meio ambiente equilibrado, bem como a fiscalização e condenação dos agentes que pratiquem as condutas lesivas, positivas ou negativas, ao meio ambiente (SARLET; FENSTERSEIFER, 2019).

A partir do novo Código Florestal (BRASIL, 2012), iniciou-se o retrocesso normativo socioambiental no país (ABESSA; FAMÁ; BURUAEM, 2019; BORINELLI; GALLASSI; MOSTAGI; MELAN, 2019; CAPELARI, et al., 2020; KRÖGER, 2017; LIMA; GARCIA, 2014; SARLET; FENSTERSEIFER, 2019), através da dominação política da direita conservadora neoliberal, centrada na oligarquia latifundiária do agrobusiness, passando a influenciar não somente através do código florestal de 2012, como também das inúmeras outras leis e normas infraconstitucionais daí decorrentes.

O tema é igualmente debatido dentro da teoria das arenas políticas de coalizão, isso porque as políticas ambientais discriminadas pelo alto grau de complexidade e conflito de sua rede (CALDWELL, 1993), abrangendo uma diversidade de problemas e fenômenos socioambientais que interagem em múltiplas escalas de tempo e espaço, como poluição, mudanças climáticas, desmatamento, biodiversidade, exaustão de recursos naturais, impactos a populações indígenas e comunidades tradicionais. Ao buscar promover a sustentabilidade nas interações socioambientais, a política ambiental permeia, questiona e mobiliza grande número de áreas de conhecimento, ideologias, atores, fronteiras geográficas, atividades econômicas e subsistemas de políticas públicas (CAPELARI, et al., 2020).

Segundo Capelari et al., (2020), grupos de interesse são "coalizões de advocacia", que produzem alianças informais sobre questões políticas, cujos membros estão unidos por certas convicções e ideologias orientadoras de como observam o mundo e como as políticas públicas deveriam ser moldadas. Essas coalizões detêm muito poder nos bastidores dos Estados e podem estar presentes no poder legislativo, executivo, judiciário, centros de tomada de decisão do governo, ONGs, Academia, Empresariado, igrejas etc., formando verdadeiras redes complexas de políticas públicas. A pesquisa desenvolvida por Capelari, et al. (2020) demonstra que, nas arenas de políticas públicas ambientais do Brasil, há o grupo dos "Desenvolvimentistas Tradicionais", que são os representantes de uma coalizão de advocacia dominante no atual subsistema de política ambiental brasileira, mas que opera em legados desde a Política de 1981. Com a urbanização e industrialização do país, grandes produtores de café da Primeira República perderam influência na condução do Estado, apesar de permanecerem como força política e econômica do país. Tal grupo é sucessor do legado do modelo agroexportador, que concentra terras (recursos naturais), utiliza trabalho escravo e se caracteriza pelo conservadorismo político (CAPELARI, et al., 2020).

Os resultados da investigação proposta por Capelari, et al. (2020) traz à tona a disputa de forças entre leis ambientais versus mercado capitalista. De fato, a coalizão dominante sempre pressionou por uma fraca regulamentação e implementação da legislação socioambiental, especialmente a federal. No entanto, a pressão internacional, a opinião pública e os movimentos conservacionistas e de direitos humanos contribuíram, em um contexto de redemocratização à época da aprovação da Política Nacional do Meio Ambiente, para a expansão da estrutura institucional e do estabelecimento, no país, do Código Ambiental Brasileiro (BRASIL, 1981) e da instauração do Estado de Direito Ambiental (LEITE, 2015; SARLET; FENSTERSEIFER, 2019) através da Carta Política (BRASIL, 1988).

Em uma retrospectiva histórica pode ser constatado que as atuais mudanças e retrocessos normativos ambientais, mais intensos e rápidos após o último pleito eleitoral de 2018, tem suas bases em dogmas cultivados desde o início do Brasil, em um jogo político intenso de alta polaridade. Na atualidade, grandes 
produtores de commodities agrícolas (por exemplo, carnes, soja, madeira e açúcar) e minerais (ferro, bauxita, manganês e nióbio) ocupam posições de destaque nessa coalizão, formada por capitais nacionais e multinacionais. Os Desenvolvimentistas Tradicionais foram os principais integrantes de um movimento neoconservador e neoliberal que venceram as eleições presidenciais brasileira de 2018 (CAPELARI, et al., 2020), que, internamente, inclui militares, evangélicos, poderosos empresários e autoritaristas em prol da redução da intervenção estatal e da influência das políticas ambientais.

Os avanços na política ambiental brasileira têm gerado conflitos e tensões permanentes e crescentes entre o subsistema de política ambiental e os setores produtivos, econômicos e de infraestrutura. A contraofensiva da coalizão dos Desenvolvimentistas Tradicionais se intensificou a partir de 2008, exigindo o relaxamento de importantes legislações regulatórias, tais como: novo Código Florestal (BRASIL, 2012), licenciamento ambiental, autorização de agrotóxicos, redução de terras indígenas e outras áreas protegidas. Porém, a primeira e principal vitória do agrobusiness foi com a reforma do código florestal brasileiro de 1965, que deu origem à Lei de Proteção a Vegetação Nativa (Lei no. 12.651/2012), a qual aumentou a exploração econômica de áreas protegidas e perdoou inadimplentes de multas ambientais pelo IBAMA.

Com essa última gestão eleita em 2018 para o Governo Federal, a coalizão dos Desenvolvimentistas Tradicionais passou a ocupar espaços estratégicos nos setores da economia e da política ambiental do governo federal, para iniciar uma fase, a qual será lembrada como um dos desmantelamentos mais escandalosos da história da política ambiental do Brasil. A ascensão dessa elite política ao poder, como coalizão dominante no subsistema ambiental, trouxe mudanças nas políticas econômicas e regulatórias, com forte ênfase na liberalização e privatização de instituições, quebra de pactos de governança e ética pública, exclusão da participação social nas câmaras de gestão paritária, desmantelamento do "Estado Administrativo", privatizações da gestão dos parques nacionais, redução ou anistia das multas ambientais, liberação de atividades mineradoras e agrícolas, bem como invasão e grilagem de terras na região Amazônica e em áreas demarcadas aos povos indígenas, flexibilização do licenciamento ambiental, privatização do monitoramento da Amazônia, venda de terras para estrangeiros na Amazônia Legal e no restante do país.

\section{O desmonte ambiental brasileiro}

\section{- Licenciamento Ambiental}

Em junho de 2004, um grupo de 25 parlamentares, apresentou o Projeto de Lei (PL) N ${ }^{\circ}$ 3729/2004 que, entre outras providências, "dispõe sobre o licenciamento ambiental e regulamenta o inciso IV do $\S 1^{\circ}$ do art. 225 da Constituição Federal" (BRASIL, 1988). Segundo os autores do projeto de lei, passados 16 anos da promulgação da CF, em 1988, os dispositivos relacionados ao estudo de impacto ambiental ainda não haviam sido regulamentados e que, por essa razão, seria motivo de insegurança jurídica nos atos de licenciamento ambiental e causa de "demanda jurídica sem precedentes no Ministério Público no que concerne aos atos administrativos públicos relacionados com o licenciamento ambiental" (BRASIL, 1988).

A Lei $n^{\circ}$ 6.938/1981 estabelece, na lista de instrumentos da Política Nacional do Meio Ambiente, a avaliação de impactos ambientais, o licenciamento e a revisão de atividades efetiva ou potencialmente poluidoras (BRASIL, 1981). Do ponto de vista dos propositores do projeto, a Resolução Conama $\mathrm{N}^{\circ}$ 001/1986 (BRASIL, 1986), que trata do estudo de impacto ambiental, do relatório de impacto ambiental e do licenciamento a Resolução Conama $n^{\circ}$ 247/1997, que trata das atividades ou empreendimento sujeitos ao licenciamento ambiental, não seriam suficientes para superação das inseguranças jurídicas originadas pela ausência de uma norma geral regulamentadora do dispositivo constitucional. Implicitamente, havia a manifestação dos propositores para necessidade de fortalecimento dos recursos humanos e materiais das estruturas operacionais dos órgãos de controle para a efetividade do processo de licenciamento ambiental no Brasil, em cumprimento ao artigo 225 CF (DIEESE, 2021).

O projeto de lei $n^{\circ} 3729 / 2004$, que tinha a finalidade de promover a segurança jurídica do processo de licenciamento ambiental por meio da regulamentação de dispositivos da Constituição Federal e, também, o fortalecimento da estrutura operacional dos órgãos licenciadores e de controle, em 2021, foi aprovado sob a 
égide da desburocratização e do combate aos excessos do quadro regulatório vigente (DIEESE, 2021). No entanto, em julho de 2019, o texto original recebeu inúmeras emendas, que descaracterizaram a proposta original e, ao final, o texto aprovado foi um substitutivo por parte da relatoria, que também acumula a função de vice-presidente da Frente Parlamentar da Agropecuária (FPA) na Câmara dos Deputados.

Em tramitação por mais de 17 anos, o projeto foi recebido pela mesa diretora da Câmara dos Deputados em 18/06/2004, tendo sido aprovado com $71 \%$ dos votos. Seu substitutivo, aprovado em maio de 2021 , por rito de votação nominal e simbólica, recebeu 300 votos pela aprovação e apenas 122 pela rejeição. Votaram por sua rejeição o Partido dos Trabalhadores (PT), o Partido Socialista Brasileiro (PSB), o Partido Democrático Trabalhista (PDT), o Partido Socialismo e Liberdade (PSOL), o Partido Comunista do Brasil (PCdoB), o Partido Verde (PV) e a Rede Sustentabilidade (Rede). Atualmente, o projeto de lei $n^{\circ} 3729 / 2004$ foi encaminhado para a apreciação no Senado Federal, agora como Projeto de Lei № 2159/2021.

O texto substitutivo aprovado traz algumas inovações como a dispensa de licenciamento ambiental para projetos de saneamento básico, obras de manutenção em estradas e portos, de distribuição de energia elétrica com baixa tensão, empreendimentos de interesse social e intervenções de pequeno porte, desde que não associadas à uma atividade listada como de licenciamento obrigatório. Para o licenciamento ambiental enquanto ato administrativo, o novo texto prevê seis modalidades de licenças: Licença Prévia (LP), Licença de Instalação (LI), Licença de Operação (LO), Licença Ambiental Única (LAU), Licença por Adesão e Compromisso (LAC) e Licença de Operação Corretiva (LOC). A LP, a LI e a LO são dispositivos existentes na legislação vigente. $O$ texto também altera os prazos de validade das licenças e mecanismos de renovação.

Dentre os diversos pontos, além da dispensa de licenciamento para obras públicas e aquelas de interesse social, destacam-se a Licença Ambiental por Adesão e Compromisso (LAC) e a Licença de Operação Corretiva (LOC). Por esse mecanismo, a licença ambiental seria concedida mediante declaração de adesão e compromisso do empreendedor que o seu empreendimento está em conformidade com os requisitos e obrigações da legislação ambiental aplicável. Essa licença estaria fundamentada apenas na preparação do Relatório de Caracterização do Empreendimento (RCE). Ressalta-se que será meramente uma licença auto declaratória, em que o empreendedor contratará e pagará pelo licenciamento, assim como será o poderdiretivo no que quer que conste em seu documento licenciador. E mais: empreendimentos de interesse social são as hidrelétricas, barragens de mineração, usinas nucleares, termelétricas etc.

Por outro lado, no caso da LOC, seria a regularização de atividade ou empreendimento que esteja operando sem licença ambiental. Importante destacar que a operação sem licenciamento ambiental é uma infração administrativa grave, prevista no artigo 70 da Lei n 9.605/1998 (Lei de Crimes Ambientais), lei esta que continua vigente e que impõe sanções da advertência até a suspensão parcial ou total das atividades. A LAU e a LOC serão concedidas com validade mínima de 5 (cinco) anos e máxima de 10 (dez) anos, em função do plano de controle ambiental. No texto aprovado pelo plenário da Câmara, há a possibilidade de renovação automática de uma licença ambiental, por igual período, mediante autodeclaração do empreendedor. Neste caso, as condicionantes seriam a não alteração das características ou do porte do empreendimento, as regras de concessão continuarem vigentes e o cumprimento do cronograma ambiental aprovado anteriormente pela autoridade licenciadora.

Espera-se um amplo debate no Senado Federal porque a repercussão do texto aprovado na Câmara foi bastante negativa entre a sociedade civil organizada, com alegações de retrocessos na gestão ambiental e que o texto afronta a Política Nacional de Meio Ambiente e a própria Constituição Federal. E, principalmente, a percepção do pensamento dominante entre os deputados que o meio ambiente é apresentado como um entrave para o desenvolvimento do País. Para a sociedade civil, significa dizer o retorno do Brasil ao final dos anos 60 .

\section{- Anistia parcial de multas ambientais}

Em 18 de outubro de 2019, o Executivo Federal apresentou à Câmara dos Deputados a Medida Provisória (MPV) 900/2019. Por meio dessa proposta, o Ministério do Meio Ambiente (MMA), estaria autorizado a contratar instituição financeira oficial em regime de dispensa de licitação, com o objetivo de criação e gestão de um 
fundo privado que receberia os recursos decorrentes de multa simples, art. 72 da Lei de Crimes Ambientais (BRASIL, 1998) a ser convertida em serviços de preservação, melhoria e recuperação da qualidade do meio ambiente e o custeio dos referidos serviços. Este mecanismo teria um período determinado de vigência de até 20 anos a partir da sua entrada em vigor.

Havia também a possibilidade do fundo receber o aporte de recursos, voluntariamente ou por decisão judicial, decorrentes de compensações ambientais ou de medidas financeiras como parte de um termo de ajustamento de conduta. $\mathrm{O}$ art. $4^{\circ}$ da MPV 900/2019 previa ainda a possibilidade de concessão de anistia parcial de até $60 \%$ sobre o valor integralizado da multa, com base em critérios que seriam futuramente estabelecidos em regulamento pelo MMA. E, também, isenta o infrator que teve a sua multa convertida de qualquer responsabilidade sobre a destinação dada aos recursos (BRASIL, 2019). Em 2018, o passivo de multas não pagas aplicadas pelo Instituto Brasileiro do Meio Ambiente e dos Recursos Naturais Renováveis (Ibama) era cerca de $\mathrm{R} \$ 38$ bilhões. A média histórica de multas aplicadas pelo lbama é de $\mathrm{R} \$ 3$ bilhões ao ano. Tomando-se o passivo de multas até 2018, o potencial total do fundo a ser criado a partir da MPV no. 900/2019 seria de R\$15,2 bilhões (ARAÚJO, 2020).

Em uma primeira vista, a MPV no. 900/2019 poderia ser interpretada como uma iniciativa pragmática, pois traria uma solução rápida e vantajosa, principalmente para o infrator, pois eliminaria medidas e recursos judiciais infindáveis, despesas advocatícias, laudos e peritagem, por exemplo. Contudo, é importante ressaltar que o princípio do poluidor-pagador da legislação ambiental é o de responsabilização pelos danos ambientais decorrentes de seus atos, não o de direito de pagar para poluir. Há claramente uma inversão de valores e que torna tal medida provisória inconstitucional ab initio, mas essa tem sido a tônica política desde 2012. A legislação ambiental brasileira prevê a responsabilização nas esferas administrativa, civil e criminal, sendo que uma não inviabiliza a outra. Com isso, as penalidades administrativas possuem caráter educativo e inibitório (MILARÉ, 2001). Felizmente, a MPV no. 900/2019 perdeu a sua eficácia em março de 2020.

\section{- Asfixia de recursos}

Outro aspecto que tem comprometido a eficácia da política pública de meio ambiente está relacionado à alocação de recursos. Em uma política com mecanismo de comando e controle, a disponibilidade dos meios financeiros, humanos e instrumentais necessários para a gestão eficaz é um fator crítico de sucesso. A Tabela 1 demonstra que os orçamentos discricionários do Instituto Chico Mendes de Conservação da Biodiversidade (ICMBio) e do Ibama têm sido sistematicamente reduzidos desde 2015. Dentre as atribuições do ICMBio, uma autarquia ligada à estrutura do Ministério do Meio Ambiente (MMA) e criada em 2007, está o poder de polícia ambiental para a proteção das Unidades de Conservação federais. O Ibama, também uma autarquia ligada à estrutura do MMA, tem poder de polícia ambiental e é executor da política ambiental no âmbito federal.

Tabela 1: Orçamentos discricionários do ICMBio e do Ibama no período de 2015 a 2021

\begin{tabular}{|c|c|c|c|c|c|c|}
\hline & \multicolumn{3}{|c|}{ ICMBio } & \multicolumn{3}{|c|}{ Ibama } \\
\hline & Autorizado (RȘ) & Liquidado (R\$̣) & Realização & Autorizado ( $\mathrm{RSS}$ ) & Liquidado (RȘ) & Realização \\
\hline 2015 & $405.274 .163,00$ & $234.221 .925,00$ & $58 \%$ & $512.190 .840,00$ & $422.382 .334,00$ & $82 \%$ \\
\hline 2016 & $284.100 .075,00$ & $233.317 .223,00$ & $82 \%$ & $334.721 .470,00$ & $287.391 .870,00$ & $86 \%$ \\
\hline 2017 & $356.519 .103,00$ & $215.218 .429,00$ & $60 \%$ & $345.331 .137,00$ & $268.466 .738,00$ & $78 \%$ \\
\hline 2018 & $295.084 .290,00$ & $227.068 .102,00$ & $77 \%$ & $378.058 .820,00$ & $304.498 .296,00$ & $81 \%$ \\
\hline 2019 & $301.863 .407,00$ & $248.772 .512,00$ & $82 \%$ & $386.885 .123,00$ & $283.840 .380,00$ & $73 \%$ \\
\hline 2020 & $209.066 .365,00$ & $168.806 .925,00$ & $81 \%$ & $316.505 .590,00$ & $233.460 .944,00$ & $74 \%$ \\
\hline 2021 & *131.175.089,00 & & & ${ }^{*} 261.000 .000,00$ & & \\
\hline
\end{tabular}

Fonte: tabela construída a partir dos dados de Werneck et al., (2021) 
Os valores apresentados na Tabela 1 foram atualizados a valor presente com base no Índice Nacional de Preços ao Consumidor Amplo (IPCA) divulgado pelo Banco Central do Brasil para cada período. O orçamento discricionário refere-se às despesas operacionais das autarquias, como fiscalização e combate à incêndios, por exemplo (WERNECK et al., 2021). O orçamento discricionário proposto na Lei Orçamentária Anual (LOA) para o ICMBio para 2021 representa apenas $32 \%$ do orçamento autorizado em 2015 . No caso do Ibama, o orçamento de 2021 é $51 \%$ do orçamento autorizado de 2015 . Outro ponto a ser observado a partir da Tabela 1 é a taxa de realização dos orçamentos autorizados. A média para o período de 2015 a 2020 foi de $73,3 \%$ para o ICMBio e $79 \%$ para o Ibama.

O Gráfico 3 apresenta a evolução do orçamento do MMA enquanto ente da estrutura da administração direta da União, somado ao das suas entidades vinculadas. Os valores apresentados foram atualizados a valor presente com base no Índice Nacional de Preços ao Consumidor Amplo (IPCA) divulgado pelo Banco Central do Brasil (WERNECK, et al., 2021). O orçamento previsto no Projeto de Lei Orçamentária Anual (PLOA) de 2021 indica o menor volume de recursos a serem alocados nos últimos 20 anos. Contudo, é possível afirmar que, de 2000 a 2014, os orçamentos autorizados e empenhados foram peças de ficção. A média dos recursos totais liquidados no período

\section{Gráfico 3: Orçamento do MMA e suas entidades vinculadas no período de 2000 a 2021}

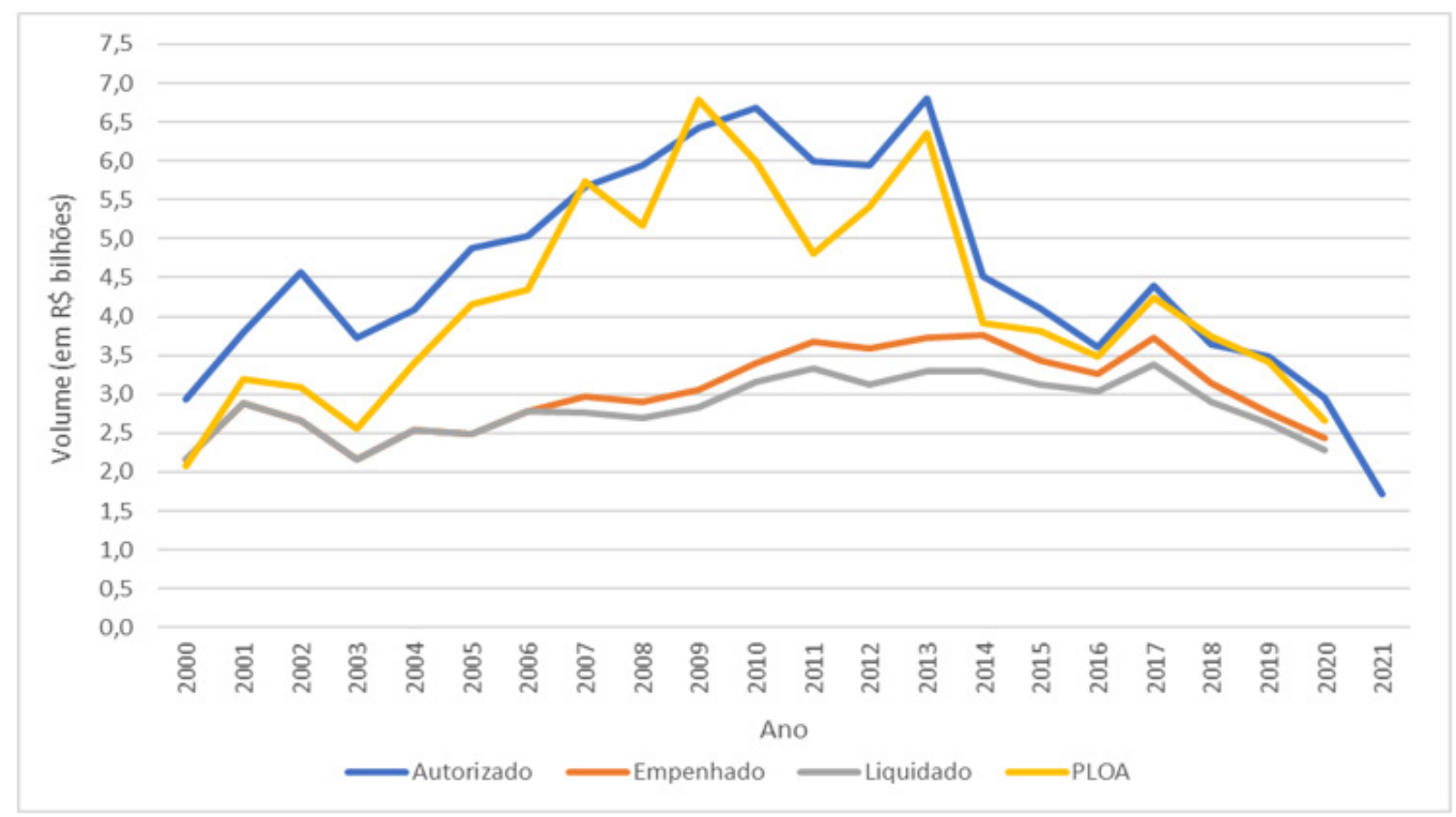

Fonte: adaptado de Werneck et al. (2021)

de 2000 a 2020 foi de $R \$ 2,83$ bilhões. Na hipótese dos recursos de $R$ \$ 1,72 bilhão previstos no PLOA para 2021 serem totalmente empenhados e liquidados, o volume de recursos será $40 \%$ inferior à média histórica do período considerado.

Confirmando-se o PLOA, o MMA - Administração Direta terá autorização para gastar apenas $\mathrm{R} \$ 4,6$ milhões, além das despesas obrigatórias e dos gastos administrativos rotineiros. Na prática, o governo acabou com as ações finalísticas do Ministério do Meio Ambiente sem ter o ônus político de extinguir a pasta (WERNECK, et al., 2021).

\section{CONSIDERAÇÕES FINAIS}

Com base nessa pesquisa, foi visto que a Política Nacional do Meio Ambiente é o Código Ambiental 
Brasileiro, que estipulou, organizou e sistematizou os instrumentos e mecanismos de gestão, controle e proteção do meio ambiente através da Lei no. 6.938/1981. Ao ser recepcionada na íntegra pela Carta Política, nos artigos 170 e 225 (BRASIL, 1988), foi estabelecido no País o Estado de Direito Ambiental no país, em que o princípio constitucional do desenvolvimento sustentável foi reconhecido para nortear o crescimento do país sem prejudicar a sustentabilidade de vida das futuras gerações.

No entanto, ficou evidente que a Política Nacional de Meio Ambiente tem sido objeto de reiteradas intervenções do Poder Executivo desde o advento do Código Florestal, de forma indireta, através de revogações de leis e resoluções que a efetivam, como que por efeito de borda, que lhe causam sua desnaturação e morte lenta. Mais especificamente a partir do último pleito eleitoral de 2018 , as atuais mudanças e retrocessos normativos ambientais, tornando inefetiva a PNMA.

Em termos de política socioambiental, se a realidade política brasileira não for revertida nos próximos anos, o país certamente caminhará para complexos e sistêmicos problemas em razão do desmantelamento sem precedentes do subsistema de Política socioambiental país. No mote da exclusão da sociedade civil e de especialistas do subsistema de políticas públicas, é necessário investigar a fundo a extensão dessa exclusão e seus impactos no processo político (CAPELARI, et al., 2020). Antes que o país se torne "terra sem lei", é preciso que os movimentos sociais e políticos pró Direitos Socioambientais, alinhem as agendas, discursos e plataformas de campanha e governo, para que se tornem uníssonos e coerentes.

Por fim, em prol do reestabelecimento do desenvolvimento sustentável e do Estado de Direito Ambiental no país, a Agenda Verde Internacional, o Pacto Sul - Sul e a presença do PNUD no Projeto Floresta+ Amazônia devem ser explorados, a fim de que forcem barreiras econômicas aos produtos do agrobusiness.

\section{AGRADECIMENTOS}

Este estudo foi parcialmente financiado pela Coordenação de Aperfeiçoamento de Pessoal de Nível Superior - Brasil (CAPES) - Código Financeiro 001.

\section{REFERÊNCIAS}

ABESSA, Denis; FAMÁ, Ana; BURUAEM, Lucas. The systematic dismantling of Brazilian environmental laws risks losses on all fronts. Nature Ecology \& Evolution, [S.L.], v. 3, n. 4, p. 510-511, 18 mar. 2019. Springer Science and Business Media LLC. http://dx.doi.org/10.1038/s41559-019-0855-9.

ARAÚJO, Suely Mara Vaz Guimarães de; CALMON, Paulo Carlos Du Pin. Política de Biodiversidade e Florestas no Brasil e Coalizões de Defesa. In: ENCONTRO DA ANPAD, 34., 2010, Rio de Janeiro - RJ. Rio de Janeiro - RJ: ENANPAD, 2010. p. 1-17.

ARAÚJO, Suely. Nota técnica sobre a MP n 900/2019 ("Fundão do Salles") e respectivo projeto de lei de conversão. Brasília: Observatório do Clima, 2020.

BARROS, Antônio Teixeira. Agenda Verde Internacional e seus impactos no Brasil. Revista de Estudos e Pesquisas sobre as Américas, Brasília - DF, v. 9, n. 2, p. 1-36, 2015.

BARROS, Dalmo Arantes et al. Breve análise dos instrumentos da política de gestão ambiental brasileira. Política \& Sociedade, Florianópolis - SC, v. 11, n. 22, p. 155-179, nov. 2012.

BOFF, Leonardo. Ética da vida: a nova centralidade. Rio de Janeiro: Record, 2009.

BORGES, Luís Antônio Coimbra; REZENDE, José Luiz Pereira de; PEREIRA, José Aldo Alves. Evolução da legislação ambiental no Brasil. Revista em Agronegócios e Meio Ambiente, Maringá - Pr, v. 2, n. 2, p. 447466, set. 2009. ISSN 1981-9951. 
BORINELLI, Benilson; GALLASSI, Juliana Nakamura; MOSTAGI, Nicole Cerci; MELAN, Rodrigo Libanez. Desregulamentação e desmantelamento ambiental: contribuições para uma análise crítica. In: SEMINÁRIO DE PESQUISA INTERDISCIPLINAR, 10, 2019, Florianópolis - SC. Florianópolis - SC: SPI, 2019. p. 1-27.

BRASIL. Constituição da República Federativa do Brasil. Brasília: Planalto, 1988. Disponível em: http:// www.planalto.gov.br/ccivil_03/constituicao/constituicao.htm. Acesso em: 26 jan. 2020.

BRASIL. Lei Federal $n^{\circ}$ 6.938, de 31 de agosto de 1981. Dispõe sobre a Política Nacional do Meio Ambiente, seus fins e mecanismos de formulação e aplicação, e dá outras providências. Brasília - DF, 02 set. 1981.

BRASIL. Lei Federal n 7.347, de 24 de julho de 1985. Disciplina a ação civil pública de responsabilidade por danos causados ao meio-ambiente, ao consumidor, a bens e direitos de valor artístico, estético, histórico, turístico e paisagístico e dá outras providências. Brasília , DF, 25 jul. 1985.

BRASIL. Lei Federal $n^{\circ}$ 9.605, de 12 de fevereiro de 1998. Dispõe sobre as sanções penais e administrativas derivadas de condutas e atividades lesivas ao meio ambiente, e dá outras providências. Brasília , DF, 13 fev. 1998. Retificada a publicação em D.O.U. em 17.02.1998.

BRASIL. Lei Federal $n^{\circ}$ 4.771, de 15 de setembro de 1965. Institui o Código Florestal. Código Florestal. Brasília , DF, 16 set. 1965. Retificada a publicação em D.O.U. em 28.09.1965.

BRASIL. Lei Federal $n^{\circ}$ 12.651, de 25 de maio de 2012. Dispõe sobre a proteção da vegetação nativa e dá outras providências. Brasília, DF, 28 maio 2012.

BRASIL. Resolução Conama $n^{\circ} 01$, de 23 de janeiro de 1986. Dispõe sobre critérios básicos e diretrizes gerais para a avaliação de impacto ambiental. Brasília , DF, 17 fev. 1986. p. 2548-2549.

BRASIL. Resolução Conama ${ }^{\circ}{ }^{237}$, de 19 de dezembro de 1997. Regulamenta os aspectos de licenciamento ambiental estabelecidos na Política Nacional do Meio Ambiente. Brasília , DF, 22 dez. 1997. n. 247, p. 30.84130.843 .

CALDWELL, Lynton K. Environmental Policy as a Political Problem. Review Of Policy Research, [S.L.], v. 12, n. 3-4, p. 104-117, set. 1993. Wiley. http://dx.doi.org/10.1111/j.1541-1338.1993.tb00555.x.

CAPELARI, M. G. M. et al. Mudança de larga escala na política ambiental: análise da realidade brasileira. Revista de Administração Pública, [S. I.], v. 54, p. 1691-1710, 16 dez. 2020.

CAPRA, Fritjof; MATEI, Ugo. A revolução ecojurídica: o direito sistêmico em sintonia com a natureza e a comunidade. São Paulo: Cultrix, 2018.

CARSON, Rachel. Primavera silenciosa. São Paulo: Editora Melhoramentos, 1969.

CARVALHO, R. C.; FÁVERO, A. A. A Teoria da Complexidade como referencial epistemológico para a pesquisa em política educacional: (re)conhecendo seus princípios e características. Revista de Estudios Teóricos y Epistemológicos en Política Educativa, v. 5, p. 1-19, 2020. Disponível em: https://www.revistas2.uepg.br/ index.php/retepe. Acesso em: 26 ago. 2020.

CARVALHO, Terciane Sabadini; DOMINGUES, Edson Paulo; HORRIDGE, J. Mark. Controlling deforestation in the Brazilian Amazon: regional economic impacts and land-use change. Land Use Policy, [S.L.], v. 64, p. 327-341, maio. 2017. Elsevier BV. http://dx.doi.org/10.1016/j.landusepol.2017.03.001. 
CAVALCANTE, L. R. Abrangência geográfica das políticas públicas de desenvolvimento regional no Brasil. Brasília: Senado Federal, abr. 2018. Disponível em: https://www12.senado.leg.br/publicacoes/estudoslegislativos/tipos-de-estudos/textos-para-discussao/td246. Acesso em: 12 jun. 2021.

CIRNE, M. B. Os princípios do desenvolvimento sustentável e da equidade nos vetos em projetos de lei ambientais. In: BENJAMIN, A. H.; LEITE, J. R. M. (org.). Direito e Sustentabilidade na era do Antropoceno: retrocesso ambiental, balanço e retrospectivas. São Paulo - Sp: Instituto O Direito Por Um Planeta Verde, 2017. Cap. 43. p. 1116-1130. (22o Congresso Brasileiro de Direito Ambiental. Teses de Estudantes de PósGraduação / PhD and Master Student's Papers). Vol. 2.

COELHO, S. O. P.;ARAÚJO, A. F. G. A sustentabilidade como princípio constitucional sistêmico e sua relevância na efetivação interdisciplinar da ordem constitucional social e econômica: para além do ambientalismo e do desenvolvimentismo. Revista da Faculdade de Direito de Uberlândia, Uberlândia - MG, v. 39, n. 1, p. 261291, jan. 2011.

COELHO, H. C. Do direito constitucional ao meio ambiente e desdobramentos principiológicos à hermenêutica (ambiental?). Veredas do Direito, Belo Horizonte - MG, v. 11, n. 21, p. 53-73, jun. 2014.

CONTI, D. M. et al. Collaborative governance towards cities sustainability transition. Urbe Revista Brasileira de Gestão Urbana, [S.L.], v. 11, p. 1-19, 2019. FapUNIFESP (SCIELO). http://dx.doi.org/10.1590/21753369.011.e20190046.

DIEESE. Subsídios para debate: Projeto de licenciamento ambiental aprovado na Câmara afrouxa legislação, libera desmatamento e ameaça a vida. São Paulo: DIEESE, maio 2021. Disponível em: https://www.dieese. org.br/outraspublicacoes/2021/sinteseEspecialLegislacaoAmbiental.html. Acesso em: 04 nov. 2021.

FERNANDES, G. W. et al. Dismantling Brazil's science threatens global biodiversity heritage. Perspectives In Ecology And Conservation, [S.L.], v. 15, n. 3, p. 239-243, jul. 2017. Elsevier BV. http://dx.doi.org/10.1016/j. pecon.2017.07.004.

FERRANTE, L.; FEARNSIDE, P. M. Brazil threatens Indigenous lands. Science, [S.L.], v. 368, n. 6490, p. 481.2482, 30 abr. 2020. American Association for the Advancement of Science (AAAS). http://dx.doi.org/10.1126/ science.abb6327.

FERREIRA, M. B. M.; SALLES, A. O. T. Política ambiental brasileira: análise histórico-institucionalista das principais abordagens estratégicas. Revista de Economia, Curitiba - PR, v. 42, n. 2, p. 1-17, 26 jul. 2017. Universidade Federal do Paraná. http://dx.doi.org/10.5380/re.v42i2.54001.

FIORI, A. M. et al. Um Painel histórico sobre a Lei Federal 6.938 de 31 de agosto de 1981 e sua importância para o direito e a gestão ambiental brasileira. 2006. Matéria publicada na Revista Eletrônica Ambiente Legal, Justiça e Política. Disponível em: http://www.ambientelegal.com.br/25-anos-a-lei-que-implantounossa-politica-ambiental-atinge-a-maturidade/. Acesso em: 01 maio 2021.

FONSECA-MORELLO, T. et al. FIRES IN BRAZILIAN AMAZON: why does policy have a limited impact? Ambiente \& Sociedade, [S.L.], v. 20, n. 4, p. 19-38, dez. 2017. FapUNIFESP (SciELO). http://dx.doi. org/10.1590/1809-4422asoc0232r1v2042017.

GIL, A. C. Métodos e técnicas de pesquisa social. 6. ed. São Paulo: Atlas, 2008.

HORSTH, T. A.; DE ALMEIDA, F. M.; MENDES, W. de A. Efeitos das recriações da Sudam e da Sudene no 
desenvolvimento socioeconômico municipal. In.: IV Encontro Brasileiro de Administração Pública, p. 17, 24 maio 2017.

JONAS, H. O princípio da responsabilidade: ensaio de uma ética para a civilização tecnológica. Rio de Janeiro: PUC - Rio, 2006. 354 p.

KREUZ, L. R. C. Constitucionalismo nos tempos do Cólera: neoconservadorismo e desnaturação constitucional. 2020. 295 f. Tese (Doutorado) - Curso de Direito do Estado, Setor de Ciências Jurídicas, Universidade Federal do Paraná, Curitiba, 2020.

KRÖGER, M. Inter-sectoral determinants of forest policy: the power of deforesting actors in post-2012 Brazil. Forest Policy And Economics, v. 77, p. 24-32, abr. 2017. Elsevier BV. http://dx.doi.org/10.1016/j. forpol.2016.06.003.

LEITE, J. R. M. (org.). Manual de Direito Ambiental. São Paulo: Saraiva, 2015. (Ebook).

LEVIS, C. et al. Help restore Brazil's governance of globally important ecosystem services. Nature Ecology \& Evolution, [S.I.], v. 4, n. 2, p. 172-173, fev. 2020. Springer Science and Business Media LLC. http://dx.doi. org/10.1038/s41559-019-1093-x.

LIMA, A. L. C.; GARCIA, J. C. O Retrocesso Normativo Ambiental no Brasil: análise dos reflexos jurídicos da globalização econômica e do neoliberalismo. Revista Direitos Humanos e Democracia, ljuí - Rs, v. 2, n. 4, p. 271-300, jul. 2014. Editora Unijuí. Disponível em: https://www.revistas.unijui.edu.br/index.php/ direitoshumanosedemocracia. Acesso em: 05 jun. 2021.

MEADOWS, D. H.; RANDERS, J.; MEADOWS, D. L. The limits to growth. White River Junction, Vt: Chelsea Green Publishing Company, 2004. Disponível em: https://www.clubofrome.org/publication/the-limits-togrowth/. Acesso em: 4 jun. 2021.

MELLO-THÉRY, N. A. Perspectivas ambientais 2019: retrocessos na política governamental. Confins, [S.L.], n. 501, p. 1-9, 7 set. 2019. OpenEdition. http://dx.doi.org/10.4000/confins. 21182.

MENEGUZZO, I. S. Apontamentos acerca da Política Nacional de Meio Ambiente. Revista de Geopolítica, Natal, v. 11, n. 1, p. 76-84, jan. 2020.

MILARÉ, E. Direito do ambiente: doutrina, prática, jurisprudência, glossário. 2. ed. São Paulo: Editora Revista dos Tribunais, 2001.

MONTIBELLER FILHO, G. M. Ecodesenvolvimento e Desenvolvimento Sustentável: conceitos e princípios. [S. I.], v. 4, n. 1, p. 11, 1993.

MORETI, G. B.; TAMIOSSO, C. F.; TAMIOSSO, M. F.; SWAROWSKY, A. Legislação ambiental: revisão dos aspectos gerais da política nacional do meio ambiente. Disciplinarum Scientia, Santa Maria, v. 18, n. 2, p. 253-264, ago. 2017.

MORIN, Edgar. A Epistemologia da Complexidade. In: MORIN, Edgar; MOIGNE, Jean-Louis Le. A Inteligência da complexidade. 2. ed. São Paulo: Pedtrópolis, 2000. p. 43-90.

ONU. Action Plan for the Human Environment. A. Framework for environmental action. 2021. Disponível em: http://www.un-documents.net/aphe-a.htm. Acesso em: 4 jun. 2021. 
ONU. Declaração de Estocolmo sobre o ambiente humano - 1972. [S. I.]: UNU, 1972. Disponível em: http://www.direitoshumanos.usp.br/index.php/Meio-Ambiente/declaracao-de-estocolmo-sobre-o-ambientehumano.html. Acesso em: 4 jun. 2021.

ONU. Our Common Future: report of the world commission on environment and development. Oslo: UN, 1987. 247 p. From A/42/427.

PALOMARES, D. S.; SANTOS, L. Z.; PIETRO, J. H. O. di. Participação popular em políticas ambientais: a democracia participativa como instrumento d concretização da sustentabilidade ambiental. Rev. Fac. Dir., Uberlândia - MG, v. 46, n. 1, p. 17-44, jun. 2018.

SACHS, I. Caminhos para o desenvolvimento sustentável. Rio de Janeiro: Garamond, 2000.

SARLET, I. W.; FENSTERSEIFER, T. O direito constitucional-ambiental brasileiro e a governança judicial ecológica: estudo à luz da jurisprudência do superior tribunal de justiça e do supremo tribunal federal. Constituição, Economia e Desenvolvimento: Revista da Academia Brasileira de Direito Constitucional, Curitiba - PR, v. 11, n. 20, p. 42-69, jul. 2019.

SAUER, S.; LEITE, S. P. Expansão Agrícola, Preços e Apropriação de Terra Por Estrangeiros no Brasil. RESR, Piracicaba - SP, v. 50, n. 3, p. 503-524, set. 2012.

SOTERRONI, A. C. et al. Future environmental and agricultural impacts of Brazil's Forest Code. Environmental Research Letters, [S.L.], v. 13, n. 7, p. 074021, 1 jul. 2018. IOP Publishing. http://dx.doi.org/10.1088/17489326/aaccbb.

SOUZA, A. S. R. O meio ambiente como direito difuso e a sua proteção como exercício de cidadania. Revista da Faculdade Mineira de Direito, Belo Horizonte - MG, v. 13, n. 25, p. 22-38, jun. 2010. ISSN 1808-9429. DOI: https://doi.org/10.5752/P.2318-7999.2010v13n25p22.

SOUZA, L. L. D.; SILVA FILHO, C. F.; MASTRODI NETO, J. A participação social como meio para o desenvolvimento sustentável. In: II SUSTENTARE E V WIPIS - WORKSHOP INTERNACIONAL SOBRE SUSTENTABILIDADE, INDICADORES E GESTÃO DE RECURSOS HÍDRICOS, 532., 2020, Campinas. Anais do II SUSTENTARE e V WIPIS - Workshop Internacional sobre Sustentabilidade, Indicadores e Gestão de Recursos Hídricos. Campinas: Puc Campinas, 2020. p. 1-16. Disponível em: www.even3.com.br/ anais/2_SUSTENTARE_5_WIPIS. Acesso em: 05 jan. 2021.

UNEP. Megadiverse Brazil: giving biodiversity an online boost. UNEP, fev. 2019. Disponível em: http://www. unep.org/news-and-stories/story/megadiverse-brazil-giving-biodiversity-online-boost. Acesso em: 12 jun. 2021.

VEIGA, J. E. da. Desenvolvimento sustentável: o desafio do século XXI. Rio de Janeiro: Garamond, 2005. VON BERTALANFFY, L. Teoria geral dos sistemas: fundamentos, desenvolvimento e aplicações. 5. ed. Petrópolis - RJ: Vozes, 2010.

WERNECK, F. et al. "Passando a boiada": O segundo ano de desmonte ambiental sob Jair Bolsonaro. [S. I.], 22 jan. 2021. Disponível em: https://www.oc.eco.br/wp-content/uploads/2021/01/Passando-a-boiada-1.pdf. Acesso em: 12 jun. 2021.

WOHLLEBEN, Peter. A vida secreta das árvores: o que elas sentem e como se comunicam. Rio de Janeiro: Sextante, 2017. 